\title{
Reporter Replicons for Antiviral Drug Discovery against Positive Single-Stranded RNA Viruses
}

\author{
Rafaela S. Fernandes ${ }^{1}\left(\mathbb{D}\right.$, Marjorie C. L. C. Freire ${ }^{1}{ }^{(0)}$, Renata V. Bueno ${ }^{1}\left(\mathbb{D}\right.$, Andre S. Godoy $^{1}(\mathbb{D}$, \\ Laura H. V. G. Gil ${ }^{2}$ and Glaucius Oliva ${ }^{1, * \mathbb{D}}$ \\ 1 Physics Institute of São Carlos, University of São Paulo, São Carlos 13566-590, SP, Brazil; \\ rafaela.fernandes@usp.br (R.S.F.); marjorie_freire_@hotmail.com (M.C.L.C.F.); \\ buenorvieira@gmail.com (R.V.B.); andre_godoy@yahoo.com.br (A.S.G.) \\ 2 Instituto Aggeu Magalhães, IAM-FIOCRUZ, Recife 50670-420, PE, Brazil; lgilfiocruz@gmail.com \\ * Correspondence: oliva@ifsc.usp.br
}

Received: 5 May 2020; Accepted: 25 May 2020; Published: 30 May 2020

\begin{abstract}
Single-stranded positive RNA ((+) ssRNA) viruses include several important human pathogens. Some members are responsible for large outbreaks, such as Zika virus, West Nile virus, SARS-CoV, and SARS-CoV-2, while others are endemic, causing an enormous global health burden. Since vaccines or specific treatments are not available for most viral infections, the discovery of direct-acting antivirals (DAA) is an urgent need. Still, the low-throughput nature of and biosafety concerns related to traditional antiviral assays hinders the discovery of new inhibitors. With the advances of reverse genetics, reporter replicon systems have become an alternative tool for the screening of DAAs. Herein, we review decades of the use of (+) ssRNA viruses replicon systems for the discovery of antiviral agents. We summarize different strategies used to develop those systems, as well as highlight some of the most promising inhibitors identified by the method. Despite the genetic alterations introduced, reporter replicons have been shown to be reliable systems for screening and identification of viral replication inhibitors and, therefore, an important tool for the discovery of new DAAs.
\end{abstract}

Keywords: replicon systems; (+) ssRNA viruses; direct-acting antivirals; drug discovery

\section{Introduction}

Single-stranded positive RNA ((+) ssRNA) viruses include a group of human pathogens with significant socioeconomic impacts, such as Dengue virus (DENV), West Nile virus (WNV), Zika virus (ZIKV), Hepatitis C virus (HCV), Severe Acute Respiratory Syndrome Coronavirus (SARS-CoV), Middle East Respiratory Syndrome Coronavirus (MERS-CoV), Severe Acute Respiratory Syndrome Coronavirus 2 (SARS-CoV-2), Poliovirus (PV), Enterovirus 71 (EV-71), Hepatitis E virus (HEV), and many others. Some members are responsible for causing significant outbreaks worldwide, as exemplified by the ZIKV pandemic 2016-2017 [1], while others, such as DENV, PV, and HEV, for example, are endemic in many tropical countries, representing a constant threat for large population groups [2]. Despite recent advances in the field of drug discovery, most of these infections remain without a satisfactory treatment [3,4]. The emergence of the new coronavirus (SARS-CoV-2) in China in 2019, which rapidly developed into a global pandemic health crisis [5,6], highlights the urgent need for effective and specific new antiviral drugs against (+) ssRNA viruses.

Due to their low-throughput nature, traditional antiviral assays, such as cytopathic effect evaluation (CPE) and viral-antigen based assays, are not ideal for testing large compound libraries [7-9]. In addition, the required biosafety level (BSL) of the facilities to manipulate viral pathogens, as most of them are classified as BSL-3 agents, is also a limiting factor for the discovery of new inhibitors. Therefore, 
antiviral development requires reliable biological assays that can be performed in a high-throughput screening (HTS) format, such as replicon-based assays [10,11].

Replicons are self-replicative subgenomic systems in which the genes encoding viral structural proteins are replaced by a reporter gene. Since mutations can only be introduced into DNA, the genomes of RNA viruses must first be reverse transcribed. The resulting complementary DNA (cDNA) can be mutagenized, generating non-infectious replicons that possess all genetic elements necessary for self-replication, but lack the structural genes responsible for the production of progeny viruses [11-13]. The correct $5^{\prime}$ and $3^{\prime}$ ends of the viral genome are crucial to the success of replicon constructs, as many viruses have specific structures at their terminals for replication and/or translation, such as a cap or a covalently linked virus-encoded peptide VPg at the $5^{\prime}$ end, can also form loop structures or have a poly-A tail in the $3^{\prime}$ end. A single restriction enzyme site inserted into the plasmid downstream of the $3^{\prime}$ end of the cDNA allows linearization before run-off in vitro transcription, resulting in a $3^{\prime}$ end of the transcribed RNA identical or as similar as possible to that of the viral genome [11,12]. In relation to the $5^{\prime}$ end, the use of bacteriophage promoters, such as T7 or SP6, allows RNA transcription with a marginally modified or even the desired start, since only a $5^{\prime} \mathrm{G}$ residue is necessary for efficient transcription by these enzymes [11,12]. Alternatively, the replicon sequence can be cloned under the control of eukaryotic promoters, such as the cytomegalovirus (CMV) promoter. In this case, transcription of the subgenomic RNA occurs in the cellular nucleus, and production of the authentic $3^{\prime}$ end is mediated by a hepatitis delta virus ribozyme (HDVr) cloned downstream of the genome. The establishment of replicon constructs driven by a CMV promoter allows for direct transfection of plasmid DNA [11,14].

Generally, a reporter gene is introduced in place of the deleted structural genes to allow luminometric (luciferases) or fluorescent (fluorescent proteins) detection of RNA replication [11,14]. To release the reporter protein, a foot-and-mouth disease virus (FMDV) 2A autoprotease is inserted downstream of the reporter gene $[11,14]$. Alternatively, the introduction of the reporter gene can be achieved by constructing bicistronic replicons with a stop codon included at the $3^{\prime}$ terminus of the insert. The reporter protein is still expressed from the $5^{\prime}$ terminal region, and translation initiation of the nonstructural proteins is then mediated by an internal ribosomal entry site (IRES) derived from the encephalomyocarditis virus (ECMV). An IRES-driven reporter gene cassette can also be inserted after the ORF into the $3^{\prime}$ UTR of the viral genome [11,14].

Transfection of susceptible cells with replicon systems results in the transient expression of the reporter protein, the level of activity of which would reflect the extent of viral replication for a limited period of time (Figure 1). Inhibitors of viral replication decrease the expression and activity of the reporter protein. This loss-of-signal end point can produce false-positive hits, resulting from molecules that interfere with the activity of the reporter protein and those that adversely affect cell health. For this reason, a cytotoxicity assay, performed in parallel with the primary screen, assists in the discovery of specific viral inhibitors [15]. Replicons can also be stably maintained in cells by introducing a drug resistance gene into the system, such as puromycin $\mathrm{N}$-acetyltransferase (Pac) or neomycin phosphotransferase (Neo), simplifying high-throughput antiviral screenings [9]. 


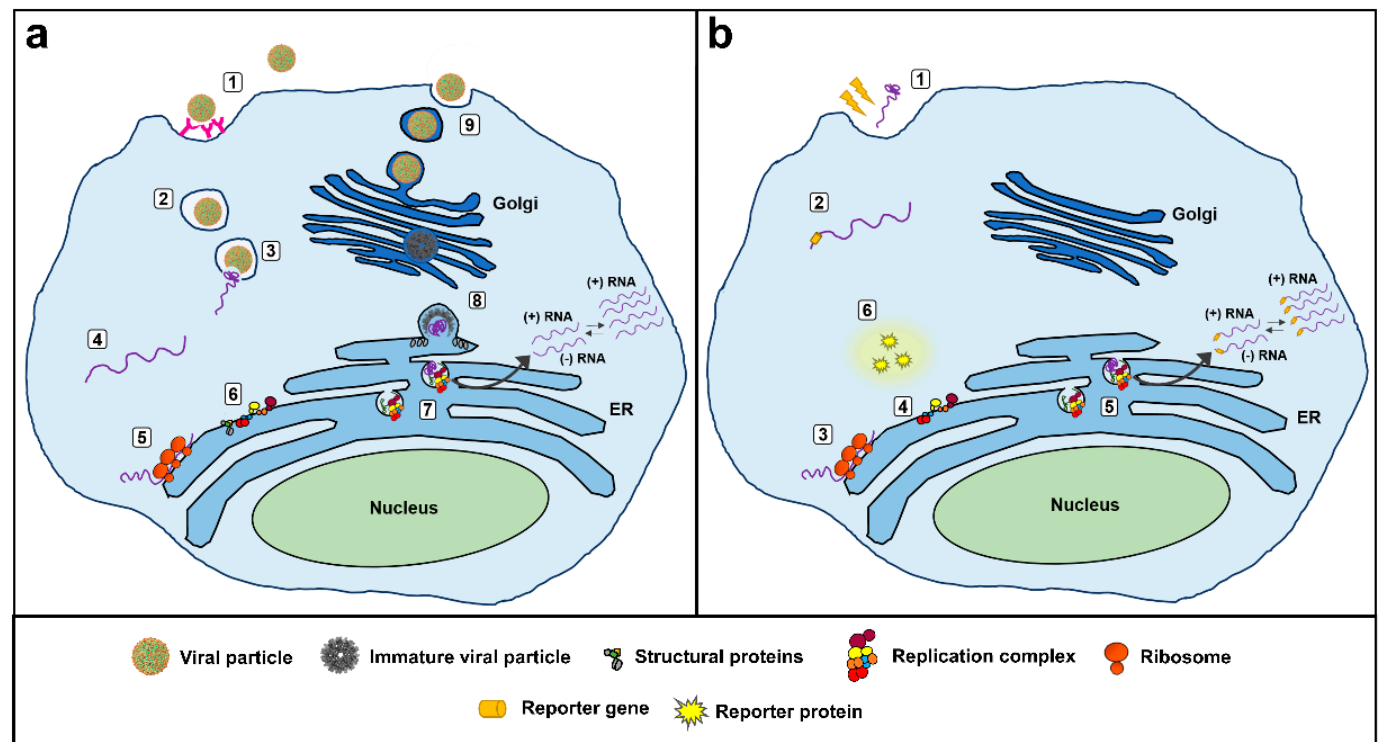

Figure 1. Schematic representation of a viral infection (a) compared to the transfection of cells with subgenomic RNA replicon systems (b). In (a), viral particles (1) are recognized by cell receptors and enter the cell via endocytosis (2). The acid environment of endosomes leads to the reorganization of the envelope glycoprotein (3), allowing the fusion of viral and endosomal membranes and the release of viral (+) ssRNA into the cytosol (4). Viral RNA hijacks the host cell's translation machinery (5) to produce structural and nonstructural proteins (6). The nonstructural proteins assemble at the endoplasmic reticulum to form the replication complex together with host cell factors (7), allowing the viral RNA replication. Nascent viral RNA is englobed by viral structural proteins, forming immature viral particles (8). Immature viral particles travel through the Golgi apparatus, where $\mathrm{pH}$ and enzymatic modifications allow particle maturation and release. In (b) in vitro transcribed replicon RNA (1) is transfected into susceptible mammalian cells. In this case, electroporation is represented by the rays because it is the most widely used physical method able to transfect a large number of cells in a short time, as it is an easy and rapid transfection option [16]. (2) Replicon RNA harbors a reporter gene in place with structural protein genes. (3) Replicon RNA hijacks the host cell's translation machinery to produce the reporter protein and nonstructural proteins. (4) Nonstructural proteins assemble at the endoplasmic reticulum to form the replication complex together with host cell factors, allowing the replicon RNA replication (5). (6) The reporter protein in the cytoplasm produces a fluorescent or luminescent signal that correlates with the level of accumulated replicon RNA, allowing the follow-up of the replicon replication efficiency.

Nevertheless, replicon-based assays allow only the discovery of molecules that affect RNA replication, but not viral entry or assembly/release. Alternatively, replicons can be packaged to produce virus replicon particles (VRPs) by providing the structural proteins in trans [11]. The expression of structural proteins in cells harboring the replicon RNA produces single-round infectious particles (SRIPs), which are infectious, but progeny viruses cannot propagate from the infected cells, as the packaged genome lacks structural protein genes [17]. VRPs allow screening of antiviral compounds that interfere with viral entry and/or RNA replication, where inhibition will result in reduced levels of the reporter protein [11].

The standard methods for developing replicon constructs, as well as the large genome size of some viruses, like Coronaviridae family members, can result in undesirable mutations or unstable/toxic clones in bacteria [12]. Therefore, the establishment of replicon systems for some viruses, such as DENV [18], WNV [19], YFV [14], HCV [20], and SARS-CoV [21], was only possible through the use of alternative hosts, low-copy plasmids, bacterial artificial chromosomes (BACs), or other improved strategies. 
In this review, we compiled the recent progress made in the use of replicon-based assays for the development of antivirals against (+) ssRNA viruses, highlighting some of the most promising inhibitors identified by the method to date.

\section{Enveloped RNA Viruses}

\subsection{Flaviviridae Family}

The Flaviviridae is a large family of spherical-shaped viruses of $\sim 40-60 \mathrm{~nm}$ in diameter, divided into four genera: Flavivirus, Hepacivirus, Pestivirus, and Pegivirus. The Flavivirus and Hepacivirus genera comprise several widely studied species, since they cause human diseases. The Flavivirus genome of $\sim 11 \mathrm{~kb}$ encodes a single polyprotein that is co- and post-translationally processed into three structural proteins: Capsid (C), pre-membrane (prM), and envelope (E), as well as seven nonstructural (NS) proteins: NS1, NS2A, NS2B, NS3, NS4A, NS4B, and NS5 (Figure 2a). Similarly, a single polyprotein is encoded by the Hepacivirus genome and cleaved into four structural proteins: Core (C), envelope proteins 1 (E1) and 2 (E2), and polypeptide 7 (p7), plus six NS proteins: NS2, NS3, NS4A, NS4B, NS5A, and NS5B. Structural proteins form the viral particles and NS proteins participate in genome replication, polyprotein cleavage, modulation of cellular processes, and evasion of host immune response [22,23].

\section{ENVELOPED RNA VIRUSES}

\section{a) FLAVIVIRIDAE}

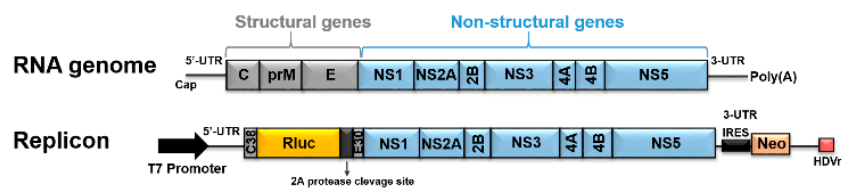

b) TOGAVIRIDAE
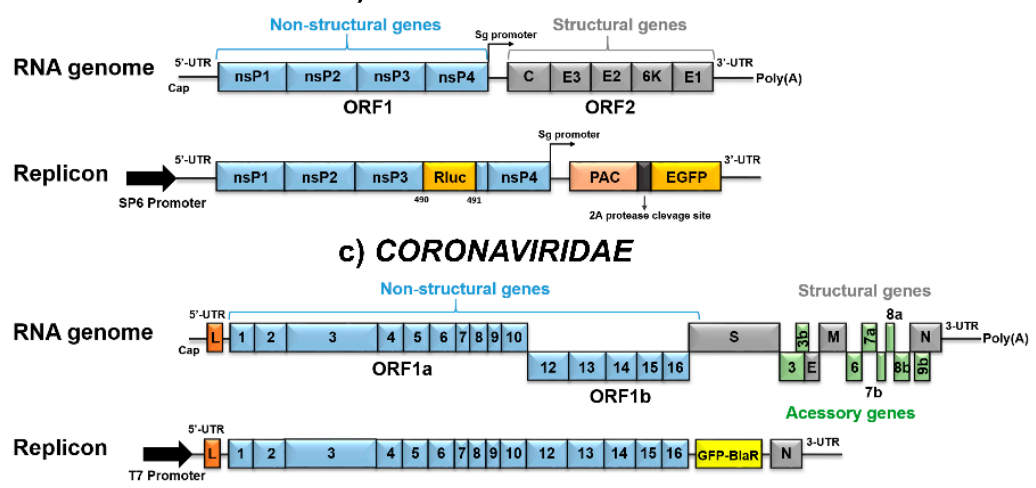

Figure 2. Schematic representation of enveloped RNA viruses' genome and subgenomic replicon systems. (a) Flaviviridae replicon based on the construct described by [8] for the Zika virus (ZIKV). $\mathrm{C}_{38}$ and $\mathrm{E}_{30}$ represent DNA sequences encoding the first 38 amino acids of $\mathrm{C}$ protein and the last 30 amino acids of E protein, respectively. A fragment containing the internal ribosomal entry site (IRES) and Neo gene was inserted downstream of the first 28 nucleotides of 3'UTR. Rluc-Renilla luciferase; HDVr-hepatitis delta virus ribozyme sequence. (b) Togaviridae replicon based on the construct described by [24] for the Chikungunya virus (CHIKV). A cassette encoding Pac fused to the enhanced green fluorescent protein (EGFP) via the 2A autoprotease of the foot-and-mouth disease virus (FMDV) was inserted under the control of the sg-promoter. In addition, the coding sequence of Rluc was inserted after the codon for amino acid 1823 of P1234 reading frame (after codon 490 of nsP3). (c) Coronaviridae replicon based on the construct described by [25] for Severe Acute Respiratory Syndrome Coronavirus (SARS-CoV). The nucleocapsid gene, $N$, was retained because the encoded protein has been shown to be required for viral RNA synthesis. Green fluorescent protein-blasticidin deaminase fusion (GFP-BlaR) gene was inserted between ORF 1 and N, not at the $5^{\prime}$ or $3^{\prime}$ end of the replicon, in order to minimize any possible deleterious effects in the synthesis of replicon RNA. $\mathrm{L}$-leader sequence. 


\subsubsection{Flavivirus}

Infections caused by flaviviruses are either asymptomatic or result in debilitating febrile illnesses that can lead to severe symptoms, such as hemorrhage, shock, and neurological disorders [3,4]. Replicon systems for antiviral assays were successfully developed for notable members, including DENV [18,26,27], WNV [10,19,28,29], Japanese encephalitis virus (JEV) [30], YFV [14,31], and ZIKV [8,9,32].

Cell-based HTS using DENV reporter replicons have identified small-molecule compounds with antiviral activities. Using Vero (African green monkey kidney) cells stably expressing a DENV-1 reporter replicon, triaryl pyrazoline was found to inhibit the viral replication without significant cytotoxicity [26]. The inhibitory effects of two flavonoid derivatives were evaluated in BHK-21 (Baby kidney hamster) cells harboring a DENV-2 replicon expressing green fluorescent protein (GFP) and Neo; however, a potential cytotoxicity was evidenced by the low selectivity index (SI) achieved for both compounds [27]. Another BHK-21 DENV-2 replicon cell line expressing firefly luciferase (Fluc) and Neo genes was used to screen a commercially available small-molecule library of 14,400 compounds, and compound 3, a benzothiazole derivative, was able to suppress the viral replication [18].

As for DENV, subgenomic replicons were also developed for WNV and used in replicon-based assays. A WNV (New York strain-lineage I) subgenomic replicon with a large in-frame deletion of structural genes, established in BHK-21 cells, was developed by Shi et al. (2002), and proved to be capable of efficiently replicating the viral RNA [19]. Then, to develop a cell-based assay, Rluc and Neo genes were engineered into the original WNV replicon, resulting in the Rluc/NeoRep. A BHK-21 cell line expressing Rluc/NeoRep was validated as an HTS tool and used to screen a 200 small-molecule library. Compound CDDMN displayed an antiviral effect represented by an SI of $>21$ [10].

Replicon systems of WNV and DENV were used to confirm the antiviral effects of compounds identified as inhibitors of the NS2B-NS3 protease in a high-throughput enzymatic screening [28]. Among 32,000 tested compounds, compound B, with a quinoline scaffold, was identified as a potent inhibitor of the NS2B-NS3 protease, possibly through the inhibition of the polyprotein cleavage, since it was also able to inhibit the viral replication of the WNV replicon [28]. Many quinoline derivatives, such as chloroquine, amodiaquine, primaquine, and others, which are Food and Drug Administration (FDA)-approved antimalarial drugs, were tested as antivirals. Amodiaquine (AQ) inhibited the replication of DENV2 Rluc reporter replicon with an $\mathrm{EC}_{50}$ value of $7.41 \pm 1.09 \mu \mathrm{M}$, suggesting a possible use as antiviral agent [33]. Using the same BHK-21 WNV and DENV2 Rluc replicon cell lines developed by Mueller et al. (2008) [28], two cathecols (compound C and tolcapone) and one polyphenolic compound (tannic acid) were described as inhibitors of dengue replication in a screen performed to test $\sim 120,000$ small-molecules [29].

JEV is a major cause of viral encephalitis in Asia and is one of the only two flaviviruses (the other one being YFV) for which an effective live-attenuated vaccine is available [30,34]. Recently, a BHK-21 cell line harboring a JEV subgenomic replicon expressing Rluc and Pac selectable marker was established and demonstrated the potential to be applied for the screening of anti-JEV compounds [30]; however, no reports on the use of replicon-based antiviral assays are available to date.

Subgenomic replicon constructions based on a full-length cDNA clone of the live-attenuated 17D strain of YFV were developed by Jones and colleagues (2005). The YFV replicon expressing an Rluc gene (YF-R.luc2A-RP) [14] was used to evaluate small-molecule inhibitors of the genome replication [31]. Sindbis virus (SINV) replicon systems expressing YFV structural proteins (SIN-CprME) were used to package YF-R.luc2A-RP constructions into pseudo-infectious virus-like particles (PIVs) [14]. For an HTS assay, YFV PIVs were used to infect a monolayer of BHK-15 cells that were then treated with more than 34,000 compounds from commercial libraries. CCG-4088 and CCG-3394, naphthalene acetamide and a morpholine derivative, respectively, efficiently inhibited YFV replication with $\mathrm{EC}_{50}$ values of 0.4 and $1.48 \mu \mathrm{M}$, respectively [31].

The 2016-2017 ZIKV outbreak in the Americas has emphasized the urgency in developing HTS assays for anti-ZIKV drug discovery [9]. A full-length infectious cDNA clone of ZIKV (strain 
FSS13025) [32] was used by Xie et al. (2016) to develop a replicon containing Rluc and Neo genes. The reporter replicon was stablished in Huh7 (human hepatocellular carcinoma) cells and validated by testing the NITD008 inhibitor $\left(\mathrm{EC}_{50}\right.$ value of $\left.0.8 \mu \mathrm{M}\right)$, a nucleoside analogue; however, the construct was not used in antiviral screenings [8]. More recently, Li and colleagues (2018) developed a Zika virus replicon harboring Rluc and Pac genes [9]. The ZIKV replicon was established in BHK-21 cells, validated using NITD008 (EC 50 of $0.52 \mu \mathrm{M}$, and a SI > 120), and used to develop an HTS assay. The assay was optimized in a 96 well plate format and validated by testing the cytotoxicity of three antiviral inhibitors, mycophenolic acid (MPA), 2'-C-methyladenosine (2'-C-MeAdo), and 6-azauridine (6-AzUrd) [9]. All compounds displayed $\mathrm{CC}_{50}$ values above $12.8 \mu \mathrm{M}$ and were also able to inhibit the luciferase activity at $2 \mu \mathrm{M}$. These results demonstrated that BHK21-ZIKV-Rep could be used to screen antiviral inhibitors of ZIKV replication [9].

\subsubsection{Hepacivirus}

Hepatitis $C$ virus is the major causative agent of non- $\mathrm{A}$, non-B viral hepatitis, affecting 170 million people worldwide. Several distinct genetic groups of $\mathrm{HCV}$ are the causative agents of human hepatitis $\mathrm{C}$, which is transmitted mainly by exposure to infective blood or blood products [35]. Chronic infection is the leading cause of liver disease worldwide, with about 71 million individuals at risk of developing liver cirrhosis and hepatocellular carcinoma [36]. The HCV is classified into seven recognized genotypes based on the viral genome sequence, with 67 confirmed and 20 provisional subtypes. Most HCV cases are caused by the genotype $1(49.1 \%)$, followed by the genotypes $3(17.9 \%), 4(16.8 \%)$, and $2(11 \%)$, all of them widely distributed around the world [37].

From the approval by the FDA in 1991 until 2014, the interferon-based therapy remained the standard treatment for chronic hepatitis. With the advent of direct-acting antiviral (DAA) drugs, the combination of pegylated-interferon- $\alpha$ (PEG-IFN- $\alpha$ ) and ribavirin was gradually replaced until the end of 2017 [38]. Since 2018, the World Health Organization (WHO) has recommended the treatment of adults with chronic HCV infection with a pan-genotypic DAA combination therapy [39]. In addition to the short-term treatment, the DAA therapeutic schemes reduced the severe side effects associated with interferon-based therapy, consequently increasing the patient adherence and the treatment effectiveness [38].

It is worthy to note the pivotal role of replicon systems in discovering HCV replication inhibitors, as previously reviewed by $[35,40]$ and more recently by [41,42]. Since the establishment of the first HCV replicon system in 1999 by Bartenschlager's group [43], when a functional replicon was developed from a genotype 1a isolate using Huh7 cells, HCV replicons have been improved by exploring distinct permissive cell lines, virus genotypes, adaptive mutations, and their relation with drug resistance. As a consequence of the well-established HCV replicon system for HTS, promising leading inhibitors of nonstructural proteins have been identified in the past years. In this context, the main targets pursued to develop DAAs are the NS proteins NS3/NS4A protease, NS5B polymerase, and NS5A.

In addition to the enzymatic assays, cell-based systems led to the discovery of peptidomimetic NS3/NS4A protease inhibitors, with replicon models extensively used to determine barriers to resistance, genotypes' susceptibility, and the inhibitors' mode of action, as exemplified by the antiviral candidate BILN 2061 [44-51]. Despite being discontinued due to cardiotoxic effects detected in pre-clinical trials, BILN 2061 was a macrocyclic inhibitor important as a proof-of-concept, as it was the first of its class active in patients infected with HCV genotype I [52]. The dose-response inhibition of NS3/NS4A by BILN 2061 was determined using HCV bicistronic NS2-NS5B subgenomic replicon 1a and 1b harbored in the Huh7 cell line, with $\mathrm{EC}_{50}$ values of 4 and $3 \mathrm{nM}$ for replicons $1 \mathrm{a}$ and $1 \mathrm{~b}$, respectively. In addition, the NS2-NS5B subgenomic replicon 1b was used to determine the BILN 2061 mechanism of inhibition by measuring its ability to block NS3-mediated polyprotein processing.

Moreover, replicon systems allowed mapping of the NS3/NS4A resistance mutations to BILN 2061 , contributing to the future design of more effective antiviral drugs $[53,54]$. Beyond the class of macrocyclic inhibitors, linear peptidomimetic inhibitors containing an alpha-ketoamide group 
that covalently binds the active site were further developed, resulting in the first-wave NS3/NS4A inhibitors, Telaprevir and Boceprevir. Telaprevir and Boceprevir were the first DAAs used to treat patients infected with HCV genotype I in association with PEG-IFN- $\alpha$ and ribavirin, and they were approved in 2012. Telaprevir and Boceprevir benefited from HCV replicon systems, which were mainly used to characterize the anti-HCV activity and to map the drug-resistance mutations. In addition, the Telaprevir cytotoxicity, clearance, and effects in association with IFN- $\alpha$ were all assessed using HCV subgenomic replicons [55] corresponding to the $I_{377}$ neo/NS3-3'/wt sequence previously described by [43].

Another molecular target extensively explored during the development of anti-HCV drugs was the NS5B RNA-dependent RNA polymerase (RdRp). The NS5B RdRp inhibitors are classified as nucleoside or non-nucleoside analogues. Currently, one of each class has been approved to treat patients with chronic hepatitis C: The non-nucleoside analogue Dasabuvir and the nucleoside analogue Sofosbuvir. The NS5B RdRp enzymatic assays as well as surrogate models like the Bovine Viral Diarrhea Virus (BVDV) were used to carry out HTS towards the discovery of anti-HCV molecules. Notwithstanding, the advent of replicons has broadened the number and the chemical diversity of promising NS5B RdRp inhibitors identified. The identification of a 2'-F-2'-C-methyl cytidine nucleoside PSI-6130 as a safe and selective inhibitor of HCV replication was performed in a replicon-based assay, in which several modifications at the $2^{\prime}-\alpha$ and $2^{\prime}-\beta$ nucleoside positions were evaluated, generating valuable structure-activity relationship information. It is worth mentioning that when tested against the BVDV, PSI-6130 did not show any activity [56]. Subgenomic and full-length HCV replicons, as well as the mutant replicon NS5B S282T, have contributed to characterizing the activity of PSI-6130, the lead molecule that originated Sofosbuvir $[40,56]$. The process of discovery and development of Sofosbuvir, considered a keystone in DAA therapy, is thoroughly described by [57].

Replicon systems have also been a valuable tool to identify anti-HCV compounds targeting proteins considered not druggable due the unavailability of in vitro enzymatic assays, such as NS5A. Despite its essential activity for RNA synthesis, viral assembly, and interaction with host proteins [58-60], the NS5A mechanism of action is barely understood and no enzymatic activity has been attributed to this protein. Performing an antiviral screening with Huh7 cells harboring HCV/BVDV dual replicon [20], Bristol-Myers Squibb researchers discovered a class of thiazolidinone derivatives with anti-HCV activity in the low nanomolar range [61]. Although this class of compounds inhibited the HCV RNA replication, it did not inhibit known enzymatic functions of nonstructural proteins, and, therefore, further investigation was carried out. For this purpose, resistant replicon cells were produced and isolated, and the drug-resistance mutations were mapped to the NS5A N-terminal domain. A single mutation with the replacement of NS5A tyrosine at position 93 by a histidine residue $(\mathrm{T} 93 \mathrm{H})$ or a combined mutation with substitution of NS5A leucine to valine at residue 31 (L31V) and glutamine to leucine at position 54 (Q54L) conferred resistance to the investigated thiazolidinone derivatives [61]. In addition, genotype Ia/lb chimeric replicons [62] were also evaluated using specific NS5A inhibitors, helping to establish the NS5A hyperphosphorylation region as the N-terminal portion involved in inhibitor sensitivity. Further development of the lead compound brought up Daclatasvir, a palindromic compound showing an $\mathrm{EC}_{50}$ against $\mathrm{Ia} / \mathrm{Ib}$ genotype replicons in the low picomolar range [63]. Daclatasvir was approved by the FDA in 2015 to treat chronic hepatitis in a combination therapy with Sofosbuvir, and its discovery and development process took huge advantage of replicon-based assays. Moreover, replicon systems contributed not only to the Daclatasvir-like HCV inhibitor development, but also helped to establish NS5A inhibition as a valuable strategy to block HCV replication. Currently, chronic hepatitis treatment with DAA combination therapy includes one of six NS5A inhibitors: Daclatasvir, Velpatasvir, Ledipasvir, Ombitasvir, Pibrentasvir, and Elbasvir.

\subsection{Togaviridae Family}

The Togaviridae family is divided into only two distinct genera: Alphavirus and Rubivirus. The genus Alphavirus comprises viruses transmitted by mosquito vectors, while the genus Rubivirus has a unique 
member, the Rubella virus (RUBV), which is spread by the aerosol route. Alphaviruses are small (60-70 $\mathrm{nm}$ in diameter) icosahedral-shaped viruses. The viral genome of about 11-12 kb contains two ORFs encoding two polyproteins: The nonstructural (nsP) or replicase polyprotein, nsP1234, which is processed into nsP1-4; and the structural polyprotein expressed via a subgenomic RNA that generates the structural proteins capsid (C), envelope (E1, E2, E3), and 6K (Figure 2b). The nsPs act in the viral replication complex, and the structural proteins are responsible for viral assembly [64].

\section{Alphavirus}

Alphavirus infections usually cause fever, rash, and arthritis, which can persist for several months. Since the re-emergence of Chikungunya virus (CHIKV) in 2013-2014, causing more than one million suspected infections in the Caribbean, as well as in the Americas, there has been an increasing interest in identifying inhibitory targets in the CHIKV replication cycle [65].

A BHK-21 cell line harboring a CHIKV replicon expressing enhanced green fluorescent protein (EGFP), Rluc, and Pac was developed and used for the screening of viral replication inhibitors [24]. The Rluc sequence was fused with CHIKV nsP3, and EGFP was produced as a fusion protein with Pac under the control of sg-promoter [24]. This system was validated for antiviral assays in 96 well format and used to test a total of 356 compounds, including 123 natural molecules, 233 clinically approved drugs, and other pharmaceutic compounds. Natural compounds with a 5,7-dihydroxyflavone structure (apigenin, chrysin, naringenin, and silybin) were found to inhibit CHIKV replicon with $\mathrm{IC}_{50}$ values ranging from 22.5 to $71.1 \mu \mathrm{M}$ [24]. Using the same CHIKV replicon cell line, an automated assay was developed in a 384 well microplate format to evaluate about 3000 bioactive compounds, including drugs approved for use as well as those in clinical trials. Of the total, six candidate molecules inhibited the RNA replication. Abamectin, ivermectin, and berberine showed about $85 \%$ decrease of the Rluc signal, while cerivastatin, fenretinide, and ivermectin compounds were less efficient, decreasing the luciferase activity in $40 \%$ to $70 \%$ [65].

Two other studies used the BHK-21 CHIKV-Rluc cell line to evaluate the anti-CHIKV activity of different flavonoids [66,67]. Among quercetin, kaempferol, and silymarin, only the latter was identified with a significant antiviral activity, suppressing the Rluc activity in $93.4 \%$ [66]. IC 50 values of 12 , 154.66, and $42.52 \mu \mathrm{M}$ were obtained for baicalein, fisetin, and quercetagetin, respectively, with fisetin displaying a high cytotoxicity in BHK-21 cells [67]. A Huh7 cell line stably expressing the CHIKV-Rluc replicon [24] was used to evaluate the effect of two class II cationic amphiphilic drugs in the viral replication [68]. Imipramine, an FDA-approved antidepressant drug, showed no cytotoxic effects and displayed a dose-dependent decrease in Rluc activity [68]. Another BHK-21 cell line harboring a Chikungunya virus replicon, derived from the infectious clone 5-pCHIKic, expressing EGFP and Fluc (CHIKrep-FlucEGFP) was developed by [69] and later used to evaluate the antiviral effects of suramin, an approved anti-parasitic drug [70]. The compound inhibited RNA synthesis and expression of the EGFP [70].

Two types of Nano luciferase (NanoLuc) CHIKV replicon, a wild type and an RdRp-inactivated replicon, were constructed and used to transfect HEK-293T (human embryonic kidney) cells to test the viral replication efficiency in the presence of Compound-A, a molecule containing a benzimidazole structure that was able to inhibit CHIKV infection at nanomolar concentrations [71]. The NanoLuc activities were measured in cell lysates at 6,12, 24, and $36 \mathrm{~h}$ post-transfection (h.p.t.), and viral genome replication of the wild-type replicon was found to be significantly inhibited at 24 and 36 h.p.t. by 106.0 and 216.7 times compared to that in the absence of Compound-A [71]. The NanoLuc activity of the RdRp-inactivated replicon was stable from 6 to 36 h.p.t., therefore demonstrating that the RdRp function was precisely inactivated and the RNA was translated until 6 h.p.t. In addition, genome translation efficiency was not affected by Compound-A. Thereby, the results demonstrated that Compound-A significantly inhibited CHIKV genome replication by targeting nsP4 protein, but did not inhibit genome translation [71]. 


\subsection{Coronaviridae Family}

Members of Coronaviridae family are the largest known RNA viruses, with 118-140 nm in diameter and with typical prominent spikes in their viral envelope. The genome of $\sim 25-32 \mathrm{~kb}$ contains two major ORFs, $1 \mathrm{a}$ and $1 \mathrm{~b}$, which encode 16 nonstructural proteins (nsp1 to 16). ORF1b is transcribed after a -1 ribosomal frameshift. The structural proteins (S, spike; $\mathrm{E}$, envelope; $\mathrm{M}$, membrane; $\mathrm{N}$, nucleocapsid) and accessory proteins are expressed from subgenomic RNAs [72] (Figure 2c).

The family is divided into two subfamilies, the Coronavirinae and the Torovirinae. In the Coronavirinae subfamily, the genus Coronavirus includes SARS-CoV and MERS-CoV, both responsible for causing serious respiratory diseases in humans with high morbidity and mortality rates [73,74]. The ongoing COVID-19 (coronavirus disease 2019) outbreak, caused by a novel coronavirus SARS-CoV-2, emerged from Wuhan, Hubei province of China, and further spread to at least 115 countries, being declared by the WHO as a "Public Health Emergency of International Concern" on January 30, 2020 [75] and as a global pandemic on March 11, 2020 [76].

\section{Coronavirus}

A SARS-CoV (Urbani strain) DNA replicon was developed as a BAC system under the control of the CMV promoter due to the large size of the genome and the instability of some $\mathrm{CoV}$ replicase gene sequences in bacteria. The replicon system was constructed with the $5^{\prime}$ and $3^{\prime}$ ends of the viral genome, the replicase, and the N genes [21]. HEK-293T cells were transfected with replicon DNA and used to confirm the effect of the triazole derivative SSYA10-001, a noncompetitive inhibitor of viral helicase (nsp13), in decreasing viral replication. SSYA10-001 showed an inhibitory activity $\left(\mathrm{EC}_{50}\right.$ value of $8.95 \mu \mathrm{M})$ with low cytotoxicity $\left(\mathrm{CC}_{50}>250 \mu \mathrm{M}\right)$, suggesting that the helicase plays a still-unidentified critical role in the SARS-CoV life cycle [77]. The compound was also shown to exhibit a broad-spectrum activity against other coronaviruses, such as MERS-CoV and Mouse Hepatitis Virus (MHV) [78].

An HTS assay using a BHK-21 SARS-CoV replicon cell line was performed to screen a total of 7035 small-molecule compounds. SARS-CoV RNA replicon construct was developed from the SIN2774 strain genome by the deletion of the envelope coding genes $\mathrm{S}, \mathrm{E}$, and $\mathrm{M}$, and insertion of a GFP co-expressed from a polyprotein containing the blasticidin-resistant gene (BlaR) selectable marker [25]. Seven compounds were identified to display an anti-SARS-CoV activity, with $\mathrm{IC}_{50}$ values ranging from 1.4 to $5.8 \mu \mathrm{M}$ [79]. Another RNA replicon system in which the $S$ gene was replaced by the EGFP was used to transiently transfect HEK-293T cells. Inhibition assays using ribavirin and the cysteine proteinase inhibitor E64-D at 12 h.p.t. showed that the E64-D was able to decrease EGFP expression at $60 \mathrm{~h}$ after treatment, indicating that the system can be used as a tool for drug screening [73].

\section{Non-Enveloped Viruses}

\subsection{Picornaviridae Family}

The Picornaviridae is one of the largest viral families, classified in eight established and five proposed genera [80]. Picornaviruses are non-enveloped icosahedral viruses responsible for causing a variety of diseases going from mild respiratory illness (rhinoviruses) to acute flaccid paralysis-AFP (polioviruses) [81]. The viral genome of about 7.0 to $8.5 \mathrm{~kb}$ is composed of a single ORF flanked by $5^{\prime}$ and $3^{\prime}$ UTR's and is covalently linked to the VPg (3B) at its $5^{\prime}$ terminus as well as polyadenylated at its $3^{\prime}$ terminus [82] (Figure 3a). The ORF encodes a single polyprotein, which, following synthesis, undergoes multiple cleavages by the two viral proteases $2 \mathrm{~A}^{\text {pro }}$ and $3 \mathrm{C}^{\text {pro }}$ to produce the final mature viral capsid proteins and nonstructural proteins [81]. 


\section{NON-ENVELOPED RNA VIRUSES}

\section{a) PICORNAVIRIDAE}

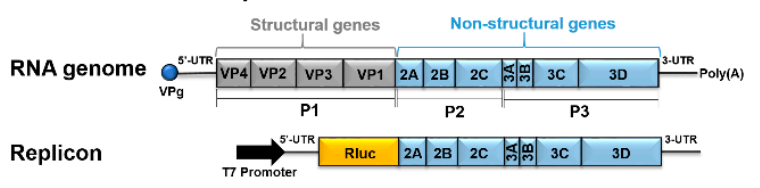

b) HEPEVIRIDAE

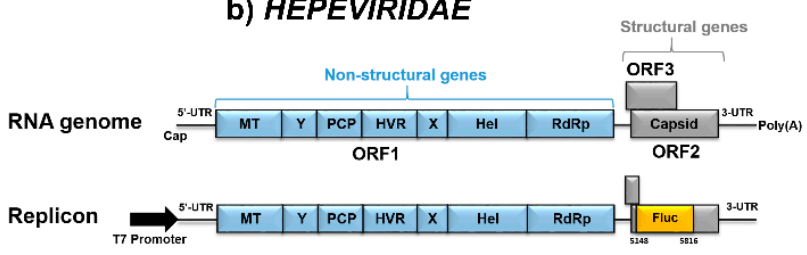

c) CALICIVIRIDAE

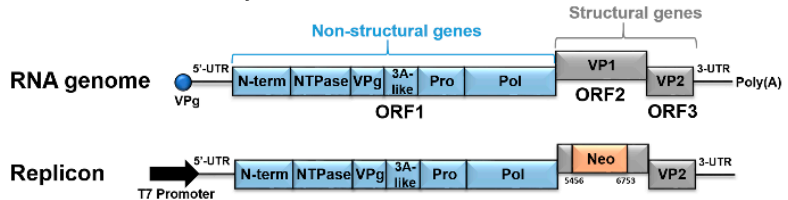

Figure 3. Schematic representation of non-enveloped RNA viruses' genomes and subgenomic replicon systems. (a) Picornaviridae replicon based on the construct described by [83] for the Poliovirus (PV). The capsid coding P1 region is replaced by the Rluc gene. (b) Hepeviridae replicon based on the construct described by [84] for the Hepatitis E virus (HEV). The ORF2 capsid gene is disrupted with the Fluc gene (nucleotides 5148 to 5816). (c) Caliciviridae replicon based on the construct described by [85] for the Norwalk virus (NV). The Neo gene was engineered into the $5^{\prime}$-end region of the ORF2 so that the expressed product would contain the first 33 aa of the NV VP1 fused in frame with neomycin phosphotransferase.

The best-known picornaviruses are EV-71, PV, Hepatitis A virus (HAV), and Human rhinovirus (HRV) [80]. Currently, only PV and HAV can be controlled by vaccination, and, therefore, antiviral therapies would be highly desirable for many picornavirus-associated diseases for which there are no approved antiviral drugs [86].

\subsubsection{Enterovirus}

Enteroviruses are ubiquitous and are common human pathogens, classified into four species formerly denominated as human enteroviruses A to D (HEV-A to HEV-D) [87]. The HEV-A members Coxsackievirus A16 (CVA16) and EV-71 are the main causative agents of hand, foot, and mouth disease (HFMD). EV-71 infections have often been associated with severe outcomes involving neurological or cardiopulmonary complications and even death $[88,89]$. Among HEV-B enteroviruses, coxsackieviruses type B (CV-B), and mainly Coxsackievirus B3 (CV-B3) are considered to be a common cause of acute myocarditis in children and young adults $[90,91]$. Poliovirus (PV), the best-studied member of the HEV-C species, is the causative agent of paralytic poliomyelitis. Although polio has been officially eradicated in Europe and in the Americas, PV is still endemic in several countries and regions [87].

Several compounds with anti-enterovirus activity have been evaluated in clinical trials, including Rupintrivir, a viral 3C protease inhibitor, and the small-molecule capsid-binding inhibitors Pirodavir and Pleconaril. However, these compounds are no longer being developed as antiviral drugs due to their limited efficacy in the context of natural infection, safety concerns, or potential drug interactions [92].

Many enterovirus subgenomic RNA replicon constructs harboring a Fluc gene in place of the capsid-code P1 region were developed for antiviral assays [87,93-95]. The antiviral effect of the thiazolobenzimidazole TBZE-029 in CV-B3 replication was evaluated in a transient assay using Buffalo green monkey (BGM) cells transfected with pCB3/T7-Luc replicon RNA in the presence (at $80 \mu \mathrm{M}$ concentration) or absence of the compound [93]. TBZE-029 almost completely inhibited the 
accumulation of viral positive-strand RNA, as evidenced by a 50-fold decrease in the Fluc activity. In this study, TBZE-029 was characterized as an inhibitor of the $2 \mathrm{C}$ protein, although the precise mechanism of action was not described [93]. Another CV-B3 inhibitor compound, the quinoline derivative Golgicide A (GCA), which specifically inhibits Golgi-specific BFA resistance factor 1 (GBF1), was tested using pCB3/T7-Luc replicon [94]. BMG cells were transfected with replicon RNA and subsequently treated with GCA. At 2, 4, 6, or 8 h.p.t. GCA was found to strongly inhibit Fluc accumulation, demonstrating that this compound hinders viral RNA replication [94].

A primary screening of 400 highly purified natural compounds was performed by $\mathrm{Xu}$ and colleagues (2014) using both subgenomic replicons and reporter EV-71 and CVA16 viruses [95]. A total of 44 compounds were identified to strongly reduce EGFP and/or luciferase expression (fluorescence and/or luminescence value $<0.5$ ) and were further evaluated by cell-viability-based secondary screening. Using CPE, plaque assay, and reporter virus-based assay, similar $\mathrm{EC}_{50}$ values were obtained for the flavonoid derivative luteolin, the most promising hit, with SI values of 14.36 and 20.03 for EV-71 and CVA16, respectively, suggesting that the molecule is a potential candidate for antiviral therapy [95].

EV-71 replicon was used in a transient assay to validate the antiviral activity of itraconazole (ITZ), a triazole antifungal agent [87]. BHK-21 cells were transfected with replicon RNA, seeded in a 12 well plate, and immediately treated with $10 \mu \mathrm{M}$ ITZ. This compound was found to decrease the Fluc activity at 16 h.p.t. at $89.2 \%$, demonstrating that ITZ strongly suppresses viral RNA replication or polyprotein processing [87]. Another study evaluated a total of 968 FDA-approved drugs as potential antivirals using both EV-71 and CV-B3 replicon systems [96]. Vero cells were transfected with EV-71 replicon RNA and simultaneously treated with the compounds at $10 \mu \mathrm{M}$ concentration. Micafungin, a well-known antifungal drug, showed an $\mathrm{IC}_{50}$ value of $\sim 5-8 \mu \mathrm{M}$ and displayed a low cytotoxicity. Similar results were obtained for Vero cells transfected with CV-B3 replicon RNA. Nevertheless, the precise mechanism of the antiviral effect of Micafungin on EV-71 was not determined [96].

The antiviral activity of compounds from a natural product library (BML-2865, Enzo Life Sciences) was evaluated in a replicon-based transient assay using EV-71 NanoLuc replicons [89]. Camptothecin, a DNA topoisomerase 1 (TOP1) inhibitor, was found to significantly inhibit the accumulation of NanoLuc in cells expressing both replication-competent and replication-incompetent replicons. The replication-incompetent construct has a 53 amino acid deletion from the C-terminus of viral RdRp 3D (3D ${ }^{\mathrm{del}}$ ) that prevents RNA replication. Therefore, the results suggested an inhibitory mechanism not specific to viral RNA replication alone, but likely implicate viral RNA translation as well [89].

A poliovirus RNA replicon with the Rluc sequence placed in frame with the polyprotein was developed by [83], and was later used for antiviral screenings. A transient replication assay was performed to evaluate the anti-PV activity of 192 cell-permeable kinase inhibitors from Calbiochem. HeLa cells were transfected with replicon RNA and replication was monitored in live cells incubated with $10 \mu \mathrm{M}$ of the compounds for $16 \mathrm{~h}$ [86]. Three compounds, Akt inhibitor IV (A4(1)), PDGF receptor tyrosine kinase inhibitor III (E5(1)), and indirubin derivative E804 E7(2), showed IC 50 values of 3.2, 12 , and $16 \mu \mathrm{M}$, respectively. However, a significant cytotoxicity was observed for A4(1) at $50 \mu \mathrm{M}$ concentration. All three compounds were effective against PV, the related CV-B3, as well as the much more distantly related EMCV from the Cardiovirus genus, evidencing the broad-spectrum effect of those molecules. Evaluation of A4(1) in vivo in a murine model of poliomyelitis showed that, although this compound had significant toxicity, it demonstrated a protective anti-poliovirus potential by delaying the development of the disease [86].

To date, more than $160 \mathrm{HRV}$ genotypes have been isolated and classified into the major groups of HRV-A, $-B$, and -C based on phylogenetic relationships [97,98]. HRV infections cause a broad spectrum of respiratory illnesses in humans, varying from a common cold to a severe and fatal pneumonia in susceptible populations [99]. Unlike HRV-A and -B, which can be propagated in conventional cell lines, HRV-C viruses were shown to only replicate in specific human airway tissues, hampering the development of screening assays for anti-HRV drugs $[99,100]$. 
A cell-based assay that can be used for antiviral screenings was successfully developed in 2014 by Mello and colleagues using subgenomic replicon systems for HRV-C. Antiviral activities of the capsid inhibitor Pleconaril, phosphatidylinositol 4-kinase III (PI4K-III) inhibitor PIK93, nucleoside analog inhibitor of 3D polymerase MK-0608, and the 3C protease inhibitor Rupintrivir were evaluated in a transient assay using H1-HeLa cells transfected with replicon constructs for genotypes HRVc24, HRVc25, HRVc15, and HRVc11 containing an Rluc sequence in the P1 capsid region. With the exception of Pleconaril, compounds inhibited the viral replication in a dose-dependent manner at low nanomolar ranges. To establish a high-throughput HRV-C antiviral screening, the HRVc15 replicon assay was optimized to a 384 well format. The results showed a robust and reproducible luciferase assay, supporting the use of this system to identify novel pan-serotype human rhinovirus inhibitors [99].

\subsubsection{Hepatovirus}

The Hepatitis A virus is the sole member of the Hepatovirus genus. HAV causes acute hepatitis and occasionally fulminant hepatitis, a life-threatening disease with a significant morbidity worldwide [101]. The risk of infection exists in countries lacking HAV immunity or where the endemicity of hepatitis A is low or intermediate, causing outbreaks that could be difficult to control. Although HAV vaccination is efficient, new therapeutic options are desired to control HAV infections [101].

The ability of amantadine, a tricyclic symmetric amine, to inhibit HAV IRES-mediated translation in Huh7 cells was reported by Kanda and colleagues in 2005, and was then evaluated in a replicon-based assay by the same group in 2010 [101,102]. Huh7 cells were transfected with pSV40-HAV-IRES vector encoding SV40 promoter-driven Rluc and Fluc, separated by HAV-IRES [102], and treated with amantadine and/or IFN- $\alpha$. Inhibition of luciferase activity was observed with amantadine with or without $100 \mathrm{IU} / \mathrm{mL}$ IFN- $\alpha$. To further characterize those inhibitory effects, a DNA replicon that stably expresses T7 RNA polymerase or a replication-incompetent HAV replicon were transfected into HuhT7 cells, and the drugs were added $24 \mathrm{~h}$ later. The results showed that the combination of amantadine and IFN- $\alpha$ can suppress HAV replication more efficiently than amantadine or IFN- $\alpha$ alone, suggesting a potential use of this drug combination to treat acute hepatitis A [101].

\subsection{Hepeviridae Family}

The Hepeviridae family is divided into two genera: Orthohepevirus, with four separate species (Orthohepevirus $A-D)$, including viruses in mammals and birds, and Piscihepevirus, with a single virus species in fish [103]. Virions are icosahedral, non-enveloped, and spherical particles with a diameter of 27 to $34 \mathrm{~nm}$ [103]. The genome of about $7.5 \mathrm{~kb}$ contains three ORFs: ORF 1, which encodes nonstructural proteins required for viral replication; ORF 2, which encodes for capsid protein; and, ORF 3 , which overlaps with ORF 2 and encodes for a phosphoprotein required for viral infectivity [104] (Figure 3b).

The Hepatitis E virus from the Orthohepevirus genus is the causative agent of hepatitis E, a self-limiting, acute, and rarely fatal disease in young adults [103]. HEV infection can be severe in patients with liver diseases and has been associated with high mortality rates among children under two years of age [105]. In addition, the mortality rates in pregnant woman reach $30 \%$, and infection can lead to chronicity in immunocompromised patients [106]. The only drug available for hepatitis E is ribavirin; still, it cannot be used by pregnant women due to the risk of fulminant hepatic failure and spontaneous abortion. Therefore, there is a need for the development of safe, non-teratogenic, and effective treatment against HEV infection [106].

Recently, two different HEV replicon systems were developed for antiviral assays. An HEV human genotype 1 (G1) Fluc replicon (pSK-HEV-2-Luc) was used to test 16 antivirals that target the RdRp [84]. NITD008 and Sofosbuvir, both nucleoside analogs, as well as GPC-N114, a non-nucleoside inhibitor, decreased the luciferase signal in a dose-dependent manner and were not toxic to the Huh7 cells, as demonstrated by the achieved SI values of $>3000,>51$, and $>93$, respectively. Next, NITD008 and GPC-N114 were evaluated in combination against HEV replicon, and demonstrated a potent 
antiviral activity and combinational synergy in vitro (mean combination index of 0.4 ), showing that both compounds could provide useful scaffolds for further antiviral development against HEV [84]. Another replicon construct, pJE03-1760F/P10-Gluc, was used to screen 767 FDA-approved compounds. In this system, the ORF 2 and ORF 3 genes were replaced by Gluc, and PLC/PRF/5 cells were used in the assay [107]. As a result, the inhibitory effects of 20 compounds were confirmed; among them, the antibiotic ciprofloxacin inhibited HEV replication and displayed low cytotoxicity. In addition, IFN- $\lambda 1-3$ were tested and also inhibited viral replication [107]. Although ciprofloxacin exhibited an inhibitory effect in the reporter system, the drug did not sufficiently inhibit HEV growth in the in vitro culture. [107] Nevertheless, the improvement of new replicon systems for HEV could help in the search for novel compounds to treat hepatitis $\mathrm{E}$.

\subsection{Caliciviridae Family}

The Caliciviridae family comprises small icosahedral viruses with a capsid displaying cup-shaped depressions and diameters between 35 and $39 \mathrm{~nm}$. The genome of $\sim 7.3$ to $9.0 \mathrm{~kb}$, with a VPg covalently linked to the $5^{\prime}$ terminus and polyadenylated at its $3^{\prime}$ terminus, contains two or three ORFs (Figure 3c). The nonstructural proteins are encoded by genome-length mRNA, and the capsid protein by subgenomic mRNA [108]. The family is divided into five genera, with two of them, Sapovirus genus and Norovirus genus, comprising human pathogens that cause acute gastrointestinal diseases [108].

Norwalk virus (NV), from the Norovirus genus, is the number one cause of foodborne illnesses around the world, responsible for extensive outbreaks of gastroenteritis [109]. The infection is generally acute and self-limiting; however, severe dehydrating diarrhea that could be fatal can occur in children, elderly, and immunocompromised individuals [110]. Regarding the treatment, there are no specific antivirals or vaccines available to prevent NV infection [110].

The major limitation for the discovery of specific compounds against noroviruses is the lack of an efficient and suitable cell culture model [110]. To develop a cell-based assay for antiviral screenings, a human norovirus replicon cell line was established by Chang et al. (2006) by transfecting a Norwalk virus RNA replicon, pNV-Neo, in which the ORF 2 was replaced by the Neo gene in Huh7 cells [85]. Viable Huh7 cell colonies bearing the NV replicon were selected with G418, and a cell clone designated HG23 was selected for further study. The replicon cell line was then incubated with increasing concentrations of IFN- $\alpha$, and the results showed that the treatment inhibited protein expression in a dose-dependent manner and no cytotoxic effects were observed [85]. The HG23 cell line was also used by the same group to test the effect of IFN- $\gamma$ and ribavirin on viral replication [111]. IFN- $\gamma$ was found to inhibit RNA replication in a dose-dependent manner, as previously reported for IFN- $\alpha$. Ribavirin also decreased viral replication, and the combination with IFN- $\gamma$ showed an additive effect on the inhibition of viral replication [111]. Thus, the results demonstrated that IFNs and ribavirin could be therapeutic options for the treatment of noroviral gastroenteritis, and confirm that the NV replicon system could be used for the screening of antiviral compounds [111].

In an effort to discover antiviral drugs against norovirus infection, different compound series were tested using the HG23 cell line. After an initial screening of peptide-conjugated phosphonodiamidite morpholino oligomers (PPMOs) using a murine norovirus (MNV) cell system, Noro 1.1, a PPMO that specifically inhibited MNV replication, also decreased protein expression and, consequently, the replication of NV replicon [112]. Another five compounds from a series of 22 amino-acid-derived acyclic sulfamide-based molecules were found to display potent inhibitory activities and low cytotoxicity against NV replicon [113]. A total of eight dipeptidyl $\alpha$-hydroxyphosphonates compounds were tested in the NV replicon cell line, and two of them showed a high inhibitory potency [114]. A compound series of tripeptidyl transition state inhibitors were synthesized and assessed for inhibitory effects using the Norwalk virus replicon cell line at concentrations ranging from 0.01 to $10 \mu \mathrm{M}$ [115]. Additionally, the compounds were tested directly against norovirus protease using a FRET-based kinetic assay to test for enzymatic activity. As results, four peptidomimetic compounds displayed anti-noroviral activity, 
decreasing replication in the sub-micromolar range [115]. Although those compounds are potential antivirals, toxicity assays must be performed to confirm their safety.

More recently, Harmalkar and colleagues (2019) reported the identification of non-nucleoside vinyl-stilbene analogs as potent norovirus replication inhibitors [116]. Some compounds were subjected to structural modifications via an empirical medicinal chemistry approach to improve their anti-noroviral activity. Then, new replication inhibition assays were performed using the HG23 cell line, and the results showed that vinyl stilbene compounds may be optimal for inhibitory activity against norovirus replication [116]. The use of the NV replicon system in the studies presented herein enabled the identification of different classes of compounds with antiviral activities and may facilitate the development of effective anti-norovirus therapeutics in the near future. With regard to the Sapovirus genus, the development of replicon systems has not been reported for any member yet.

\section{Conclusions}

Over the past decades, several replicon-based systems have been developed for the discovery of DAA targeting (+) ssRNA viruses (Figure 4). Despite the genetic modifications inserted into the viral genome sequence, including the deletion of partial or entire structural protein coding sequences and insertion of different reporter genes, the system remains a safe and reliable tool for screening large compound libraries. This may be exemplified by HCV, for which the use of reporter replicon systems was pivotal for the discovery of new DAAs, such as Sofosbuvir and Daclatasvir, both approved by the FDA to treat chronic hepatitis in a combination therapy [57,63]. Moreover, replicon-based assays have also been a valuable tool to identify antiviral compounds targeting proteins considered not druggable due to the lack of in vitro enzymatic assays, like HCV NS5A [63]. Notwithstanding, development of cell-based assays for some viruses that proved difficult to culture in common cell lines, such as HRV-C viruses and noroviruses, was made possible through the establishment of replicon systems, allowing the screening for inhibitors of the viral replication. Finally, the use of reporter replicons has enabled the identification of several small-molecule compounds displaying effective antiviral activities on low nanomolar ranges with high selectivity, providing useful scaffolds for further DAA development against enveloped and non-enveloped (+) ssRNA viruses (Table 1).

Table 1. Compounds identified as antiviral inhibitors using replicon-based assays.

\begin{tabular}{|c|c|c|}
\hline Virus & Inhibitor & Current Status \\
\hline \multirow{4}{*}{ DENV } & Triaryl pyrazoline [26] & In vitro assays \\
\hline & Amodiaquine (AQ) [33] & Approved \\
\hline & Compound C and tolcapone [28] & In vitro assays \\
\hline & Tannic acid [29] & In vitro assays \\
\hline \multirow{2}{*}{ WNV } & Compound CDDMN [10] & In vitro assays \\
\hline & Compound B [28] & In vitro assays \\
\hline YFV & CCG-4088 and CCG-3394 [31] & In vitro assays \\
\hline \multirow{3}{*}{ ZIKV } & Mycophenolic acid (MPA) [9] & Approved \\
\hline & 2'-C-methyladenosine (2'-C-MeAdo) [9] & In vitro assays \\
\hline & 6-azauridine (6-AzUrd) [9] & In vitro assays \\
\hline \multirow{6}{*}{$\mathrm{HCV}$} & BILN 2061 [54] & Pre-clinical trials (discontinued) \\
\hline & Telaprevir [55] & Approved \\
\hline & Boceprevir [55] & Approved \\
\hline & PSI-6130 (lead molecule of Sofosbuvir) $[40,56]$ & Approved (Sofosbuvir) \\
\hline & Thiazolidinone derivatives [61] & In vitro assays \\
\hline & Daclatasvir [63] & Approved \\
\hline
\end{tabular}


Table 1. Cont.

\begin{tabular}{|c|c|c|}
\hline Virus & Inhibitor & Current Status \\
\hline \multirow{10}{*}{ CHIKV } & 5,7-dihydroxyflavone derivatives [64] & In vitro assays \\
\hline & Abamectin [65] & Approved \\
\hline & Ivermectin [65] & Approved \\
\hline & Berberine [65] & Approved \\
\hline & Cerivastatin [65] & Approved \\
\hline & Fenretinide [65] & Approved \\
\hline & Silymarin [66] & Approved \\
\hline & Imipramine [68] & Approved \\
\hline & Suramin $[70]$ & Approved \\
\hline & Compound-A [71] & In vitro assays \\
\hline \multirow{3}{*}{ SARS-COV } & Compound SSYA10-001 [77] & In vitro assays \\
\hline & Ribavirin [73] & Approved \\
\hline & E64-d [73] & In vitro assays \\
\hline \multirow{3}{*}{ CV-B3 } & Thiazolobenzmidazole (TBZE-029) [93] & In vitro assays \\
\hline & Golgicide A (GCA) [94] & In vitro assays \\
\hline & Micafungin [96] & Approved \\
\hline \multirow{4}{*}{ EV-71 } & Luteolin [95] & In vitro assays \\
\hline & Itraconazole [87] & Approved \\
\hline & Micafungin [96] & Approved \\
\hline & Camptothecin [89] & In vitro assays \\
\hline CVA16 & Luteolin [95] & In Vitro assays \\
\hline \multirow{3}{*}{ PV } & Akt inhibitor IV (A4(1)) [86] & Pre-clinical trials \\
\hline & PDGF receptor tyrosine kinase inhibitor III (E5(1)) [86] & In vitro assays \\
\hline & Indirubin derivative E804 E7(2) [86] & In vitro assays \\
\hline \multirow{4}{*}{ HRV-C } & Pleconaril [99] & Clinical trial (discontinued) \\
\hline & PIK93 [99] & In vitro assays \\
\hline & MK-0608 [99] & In vitro assays \\
\hline & Rupintrivir [99] & Clinical trials \\
\hline \multirow{2}{*}{ HAV } & Amantadine [101] & Approved \\
\hline & IFN-alpha [101] & Approved \\
\hline \multirow{5}{*}{ HEV } & NITD008 [84] & In vitro assays \\
\hline & Sofosbuvir [84] & Approved \\
\hline & GPC-N114 [84] & In vitro assays \\
\hline & Ciprofloxacin [107] & Approved \\
\hline & IFN-gama 1-3 [107] & Approved \\
\hline \multirow{8}{*}{ NV } & IFN-alpha [85] & Approved \\
\hline & IFN-gama [111] & Approved \\
\hline & Ribavirina [111] & Approved \\
\hline & $\begin{array}{l}\text { Peptide-conjugated phosphonodiamidite morpholino } \\
\text { oligomers (PPMOs) [112] }\end{array}$ & In vitro assays \\
\hline & Amino acid-derived acyclic sulfamide-based compounds [113] & In vitro assays \\
\hline & Dipeptidyl $\alpha$-hydroxyphosphonates compounds [114] & In vitro assays \\
\hline & Tripeptidyl transition state compounds [115] & In vitro assays \\
\hline & Non-nucleoside vinyl-stilbene analogs [116] & In vitro assays \\
\hline
\end{tabular}


<smiles>CCN(CC)Cc1ccc(Nc2ccc(Cl)cc2N(C)C)c(O)c1</smiles>

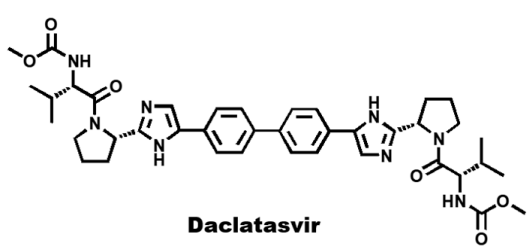

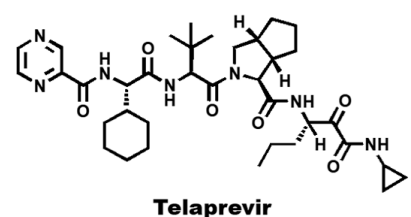

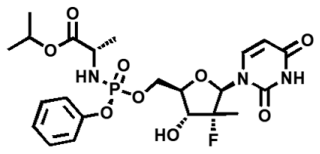

Sofosbuvir

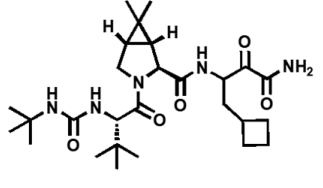

Boceprevir

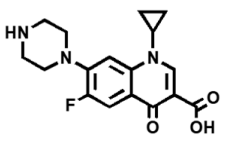

Ciprofloxacin

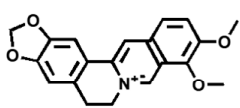

Berberine

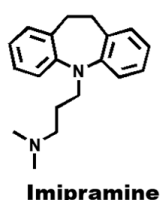

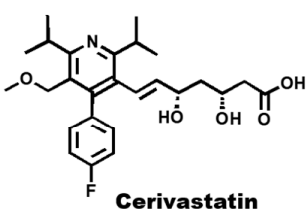

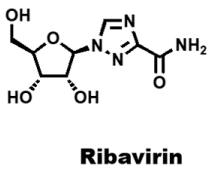

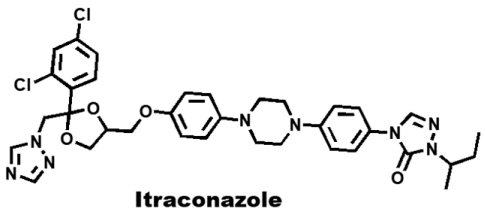

Itraconazole

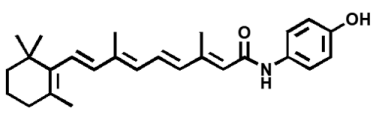

Fenretinide

Figure 4. Two-dimensional structures of approved antivirals against single-stranded positive RNA $((+)$ ssRNA) viruses.

Author Contributions: The authors contributed equally to all aspects of the article. All authors have read and agreed to the published version of the manuscript.

Funding: This work was supported by Fundação de Amparo à Pesquisa do Estado de São Paulo (FAPESP-CEPID grant 2013/07600-3 and grants 2018/05130-3, 2018/17095-8, and 2016/19712-9) and Conselho Nacional de Desenvolvimento Científico e Tecnológico (CNPq — grants 400773/2019-8 and 151058/2018-0).

Conflicts of Interest: The authors declare no conflict of interest. The funders had no role in the design of the study; in the collection, analyses, or interpretation of data; in the writing of the manuscript, or in the decision to publish the results.

\section{References}

1. Morens, D.M.; Fauci, A.S. Pandemic Zika: A Formidable Challenge to Medicine and Public Health. J. Infect. Dis. 2017, 216, S857-S859. [CrossRef]

2. Bhatt, S.; Gething, P.W.; Brady, O.J.; Messina, J.P.; Farlow, A.W.; Moyes, C.L.; Drake, J.M.; Brownstein, J.S.; Hoen, A.G.; Sankoh, O.; et al. The global distribution and burden of dengue. Nature 2013, 496, 504-507. [CrossRef]

3. Hayes, E.B. Is it time for a new yellow fever vaccine? Vaccine 2010, 28, 8073-8076. [CrossRef]

4. Monath, T.P. Review of the risks and benefits of yellow fever vaccination including some new analyses. Expert Rev. Vaccines 2012, 11, 427-448. [CrossRef]

5. Huang, C.; Wang, Y.; Li, X.; Ren, L.; Zhao, J.; Hu, Y.; Zhang, L.; Fan, G.; Xu, J.; Gu, X.; et al. Clinical features of patients infected with 2019 novel coronavirus in Wuhan, China. Lancet 2020. [CrossRef]

6. Chan, J.F.-W.; Kok, K.-H.; Zhu, Z.; Chu, H.; To, K.K.-W.; Yuan, S.; Yuen, K.-Y. Genomic characterization of the 2019 novel human-pathogenic coronavirus isolated from a patient with atypical pneumonia after visiting Wuhan. Emerg. Microbes Infect. 2020, 9, 221-236. [CrossRef]

7. Morrey, J.D.; Smee, D.F.; Sidwell, R.W.; Tseng, C. Identification of active antiviral compounds against a New York isolate of West Nile virus. Antivir. Res. 2002, 55, 107-116. [CrossRef] 
8. Xie, X.; Zou, J.; Shan, C.; Yang, Y.; Kum, D.B.; Dallmeier, K.; Neyts, J.; Shi, P.Y. Zika Virus Replicons for Drug Discovery. EBioMedicine 2016, 12, 156-160. [CrossRef]

9. Li, J.Q.; Deng, C.L.; Gu, D.; Li, X.; Shi, L.; He, J.; Zhang, Q.Y.; Zhang, B.; Ye, H.Q. Development of a replicon cell line-based high throughput antiviral assay for screening inhibitors of Zika virus. Antivir. Res. 2018, 150, 148-154. [CrossRef]

10. Puig-Basagoiti, F.; Deas, T.S.; Ren, P.; Tilgner, M.; Ferguson, D.M.; Shi, P.-Y. High-throughput assays using a luciferase-expressing replicon, virus-like particles, and full-length virus for West Nile virus drug discovery. Antimicrob. Agents Chemother. 2005, 49, 4980-4988. [CrossRef]

11. Kümmerer, B.M. Establishment and Application of Flavivirus Replicons. In Advances in Experimental Medicine and Biology; Springer Nature Switzerland AG: Basel, Switzerland, 2018; Volume 1062, pp. 165-173.

12. Tews, B.A.; Meyers, G. Self-Replicating RNA. Methods Mol. Biol. 2017, 1499, 15-35. [CrossRef]

13. Aubry, F.; Nougairede, A.; de Fabritus, L.; Querat, G.; Gould, E.A.; de Lamballerie, X. Single-stranded positive-sense RNA viruses generated in days using infectious subgenomic amplicons. J. Gen. Virol. 2014, 95, 2462-2467. [CrossRef]

14. Jones, C.T.; Patkar, C.G.; Kuhn, R.J. Construction and applications of yellow fever virus replicons. Virology 2005, 331, 247-259. [CrossRef]

15. Green, N.; Ott, R.D.; Isaacs, R.J.; Fang, H. Cell-based assays to identify inhibitors of viral disease. Expert Opin. Drug Discov. 2008. [CrossRef]

16. Kim, T.K.; Eberwine, J.H. Mammalian cell transfection: The present and the future. Anal. Bioanal. Chem. 2010, 397, 3173-3178. [CrossRef]

17. Suzuki, R.; Ishikawa, T.; Konishi, E.; Matsuda, M.; Watashi, K.; Aizaki, H.; Takasaki, T.; Wakita, T. Production of single-round infectious chimeric flaviviruses with DNA-based Japanese encephalitis virus replicon. J. Gen. Virol. 2014, 95, 60-65. [CrossRef]

18. Hsu, Y.-C.; Chen, N.-C.; Chen, P.-C.; Wang, C.-C.; Cheng, W.-C.; Wu, H.-N. Identification of a small-molecule inhibitor of dengue virus using a replicon system. Arch. Virol. 2012, 157, 681-688. [CrossRef]

19. Shi, P.Y.; Tilgner, M.; Lo, M.K. Construction and characterization of subgenomic replicons of New York strain of West Nile virus. Virology 2002, 296, 219-233. [CrossRef]

20. O’Boyle, D.R.; Nower, P.T.; Lemm, J.A.; Valera, L.; Sun, J.H.; Rigat, K.; Colonno, R.; Gao, M. Development of a cell-based high-throughput specificity screen using a hepatitis $\mathrm{C}$ virus-bovine viral diarrhea virus dual replicon assay. Antimicrob. Agents Chemother. 2005, 49, 1346-1353. [CrossRef]

21. Almazan, F.; DeDiego, M.L.; Galan, C.; Escors, D.; Alvarez, E.; Ortego, J.; Sola, I.; Zuniga, S.; Alonso, S.; Moreno, J.L.; et al. Construction of a Severe Acute Respiratory Syndrome Coronavirus Infectious cDNA Clone and a Replicon To Study Coronavirus RNA Synthesis. J. Virol. 2006, 80, 10900-10906. [CrossRef]

22. Lindenbach, B.D.; Thiel, H.-J.; Rice, C.M. Flaviviridae: The Viruses and Their Replication. In Fields Virology, 5th ed.; Lippincott-Raven Publishers: Philadelphia, PA, USA, 2007; pp. 1101-1152.

23. Kuhn, R.J.; Zhang, W.; Rossmann, M.G.; Pletnev, S.V.; Corver, J.; Lenches, E.; Jones, C.T.; Mukhopadhyay, S.; Chipman, P.R.; Strauss, E.G.; et al. Structure of Dengue Virus: Implications for Flavivirus Organization, Maturation, and Fusion. Cell 2002, 108, 717-725. [CrossRef]

24. Pohjala, L.; Utt, A.; Varjak, M.; Lulla, A.; Merits, A.; Ahola, T.; Tammela, P. Inhibitors of Alphavirus Entry and Replication Identified with a Stable Chikungunya Replicon Cell Line and Virus-Based Assays. PLoS ONE 2011, 6, e28923. [CrossRef]

25. Ge, F.; Luo, Y.; Liew, P.X.; Hung, E. Derivation of a novel SARS-coronavirus replicon cell line and its application for anti-SARS drug screening. Virology 2007, 360, 150-158. [CrossRef]

26. Puig-Basagoiti, F.; Tilgner, M.; Forshey, B.M.; Philpott, S.M.; Espina, N.G.; Wentworth, D.E.; Goebel, S.J.; Masters, P.S.; Falgout, B.; Ren, P.; et al. Triaryl pyrazoline compound inhibits flavivirus RNA replication. Antimicrob. Agents Chemother. 2006, 50, 1320-1329. [CrossRef]

27. Leardkamolkarn, V.; Sirigulpanit, W. Establishment of a Stable Cell Line Coexpressing Dengue Virus-2 and Green Fluorescent Protein for Screening of Antiviral Compounds. J. Biomol. Screen. 2012, 17, $283-292$. [CrossRef]

28. Mueller, N.H.; Pattabiraman, N.; Ansarah-Sobrinho, C.; Viswanathan, P.; Pierson, T.C.; Padmanabhan, R. Identification and biochemical characterization of small-molecule inhibitors of west nile virus serine protease by a high-throughput screen. Antimicrob. Agents Chemother. 2008, 52, 3385-3393. [CrossRef] 
29. Balasubramanian, A.; Manzano, M.; Teramoto, T.; Pilankatta, R.; Padmanabhan, R. High-throughput screening for the identification of small-molecule inhibitors of the flaviviral protease. Antivir. Res. 2016, 134, 6-16. [CrossRef]

30. Zhang, Q.-Y.; Li, X.-D.; Liu, S.-Q.; Deng, C.-L.; Zhang, B.; Ye, H.-Q. Development of a stable Japanese encephalitis virus replicon cell line for antiviral screening. Arch. Virol. 2017, 162, 3417-3423. [CrossRef]

31. Patkar, C.G.; Larsen, M.; Owston, M.; Smith, J.L.; Kuhn, R.J. Identification of Inhibitors of Yellow Fever Virus Replication Using a Replicon-Based High-Throughput Assay. Antimicrob. Agents Chemother. 2009, 53, 4103-4114. [CrossRef]

32. Shan, C.; Xie, X.; Muruato, A.E.; Rossi, S.L.; Roundy, C.M.; Azar, S.R.; Yang, Y.; Tesh, R.B.; Bourne, N.; Barrett, A.D.; et al. An Infectious cDNA Clone of Zika Virus to Study Viral Virulence, Mosquito Transmission, and Antiviral Inhibitors. Cell Host Microbe 2016, 19, 891-900. [CrossRef]

33. Boonyasuppayakorn, S.; Reichert, E.D.; Manzano, M.; Nagarajan, K.; Padmanabhan, R. Amodiaquine, an antimalarial drug, inhibits dengue virus type 2 replication and infectivity. Antivir. Res. 2014, 106, 125-134. [CrossRef]

34. Hennessy, S.; Strom, B.L.; Bilker, W.B.; Zhengle, L.; Chao-Min, W.; Hui-Lian, L.; Tai-Xiang, W.; Hong-Ji, Y.; Qi-Mau, L.; Tsai, T.F.; et al. Effectiveness of live-attenuated Japanese encephalitis vaccine (SA14-14-2): A case-control study. Lancet 1996, 347, 1583-1586. [CrossRef]

35. Horscroft, N.; Lai, V.C.; Cheney, W.; Yao, N.; Wu, J.Z.; Hong, Z.; Zhong, W. Replicon Cell Culture System as a Valuable Tool in Antiviral Drug Discovery against Hepatitis C Virus. Antivir. Chem. Chemother. 2005, 16, 1-12. [CrossRef]

36. Neufeldt, C.J.; Cortese, M.; Acosta, E.G.; Bartenschlager, R. Rewiring cellular networks by members of the Flaviviridae family. Nat. Rev. Microbiol. 2018, 16, 125-142. [CrossRef]

37. Petruzziello, A.; Marigliano, S.; Loquercio, G.; Cozzolino, A.; Cacciapuoti, C. Global epidemiology of hepatitis $C$ virus infection: An up-date of the distribution and circulation of hepatitis $C$ virus genotypes. World J. Gastroenterol. 2016, 22, 7824. [CrossRef]

38. Alqahtani, S.A.; Sulkowski, M.S. The Role of Interferon for the Treatment of Chronic Hepatitis C Virus Infection. In HCV: The Journey from Discovery to a Cure; Springer: Cham, Switzerland, 2009; pp. 223-247. [CrossRef]

39. World Health Organization. Guidelines for the Care and Treatment of Persons Diagnosed with Chronic Hepatitis $C$ Virus Infection; World Health Organization: Geneva, Switzerland, 2018; ISBN 9789241550345.

40. Delang, L.; Neyts, J.; Vliegen, I.; Abrignani, S.; Neddermann, P.; De Francesco, R. Hepatitis C Virus-Specific Directly Acting Antiviral Drugs. In Current Topics in Microbiology and Immunology; Bartenschlager, R., Ed.; Springer Nature Switzerland AG: Basel, Switzerland, 2013; Volume 369, pp. 289-320, ISBN 978-3-642-27339-1.

41. Lohmann, V. Hepatitis C virus cell culture models: An encomium on basic research paving the road to therapy development. Med. Microbiol. Immunol. 2019, 208, 3-24. [CrossRef]

42. Luna, J.M.; Saeed, M.; Rice, C.M. Taming a beast: Lessons from the domestication of hepatitis C virus. Curr. Opin. Virol. 2019, 35, 27-34. [CrossRef]

43. Lohmann, V.; Körner, F.; Koch, J.-O.; Herian, U.; Theilmann, L.; Bartenschlager, R. Replication of Subgenomic Hepatitis C Virus RNAs in a Hepatoma Cell Line. Science 1999, 285, 110-113. [CrossRef]

44. Tomei, L.; Failla, C.; Santolini, E.; De Francesco, R.; La Monica, N. NS3 is a serine protease required for processing of hepatitis C virus polyprotein. J. Virol. 1993, 67, 4017-4026. [CrossRef]

45. Grakoui, A.; McCourt, D.W.; Wychowski, C.; Feinstone, S.M.; Rice, C.M. Characterization of the hepatitis C virus-encoded serine proteinase: Determination of proteinase-dependent polyprotein cleavage sites. J. Virol. 1993, 67, 2832-2843. [CrossRef]

46. Bartenschlager, R.; Lohmann, V.; Wilkinson, T.; Koch, J.O. Complex formation between the NS3 serine-type proteinase of the hepatitis C virus and NS4A and its importance for polyprotein maturation. J. Virol. 1995, 69, 7519-7528. [CrossRef] [PubMed]

47. Bartenschlager, R.; Ahlborn-Laake, L.; Mous, J.; Jacobsen, H. Nonstructural protein 3 of the hepatitis C virus encodes a serine-type proteinase required for cleavage at the NS3/4 and NS4/5 junctions. J. Virol. 1993, 67, 3835-3844. [CrossRef] [PubMed]

48. Failla, C.; Tomei, L.; De Francesco, R. Both NS3 and NS4A are required for proteolytic processing of hepatitis C virus nonstructural proteins. J. Virol. 1994, 68, 3753-3760. [CrossRef] [PubMed] 
49. Bartenschlager, R.; Ahlborn-Laake, L.; Yasargil, K.; Mous, J.; Jacobsen, H. Substrate determinants for cleavage in cis and in trans by the hepatitis C virus NS3 proteinase. J. Virol. 1995, 69, 198-205. [CrossRef] [PubMed]

50. Lin, C.; Thomson, J.A.; Rice, C.M. A central region in the hepatitis C virus NS4A protein allows formation of an active NS3-NS4A serine proteinase complex in vivo and in vitro. J. Virol. 1995, 69, 4373-4380. [CrossRef] [PubMed]

51. Bartenschlager, R.; Ahlborn-Laake, L.; Mous, J.; Jacobsen, H. Kinetic and structural analyses of hepatitis C virus polyprotein processing. J. Virol. 1994, 68, 5045-5055. [CrossRef]

52. Lamarre, D.; Anderson, P.C.; Bailey, M.; Beaulieu, P.; Bolger, G.; Bonneau, P.; Bös, M.; Cameron, D.R.; Cartier, M.; Cordingley, M.G.; et al. An NS3 protease inhibitor with antiviral effects in humans infected with hepatitis C virus. Nature 2003, 426, 186-189. [CrossRef]

53. Lu, L.; Pilot-Matias, T.J.; Stewart, K.D.; Randolph, J.T.; Pithawalla, R.; He, W.; Huang, P.P.; Klein, L.L.; Mo, H.; Molla, A. Mutations conferring resistance to a potent hepatitis $\mathrm{C}$ virus serine protease inhibitor in vitro. Antimicrob. Agents Chemother. 2004, 48, 2260-2266. [CrossRef]

54. Lin, C.; Lin, K.; Luong, Y.P.; Rao, B.G.; Wei, Y.Y.; Brennan, D.L.; Fulghum, J.R.; Hsiao, H.M.; Ma, S.; Maxwell, J.P.; et al. In vitro resistance studies of hepatitis $C$ virus serine protease inhibitors, VX-950 and BILN 2061: Structural analysis indicates different resistance mechanisms. J. Biol. Chem. 2004, 279, 17508-17514. [CrossRef]

55. Lin, K.; Perni, R.B.; Kwong, A.D.; Lin, C. VX-950, a novel hepatitis C virus (HCV) NS3-4A protease inhibitor, exhibits potent antiviral activities in HCV replicon cells. Antimicrob. Agents Chemother. 2006, 50, 1813-1822. [CrossRef]

56. Stuyver, L.J.; McBrayer, T.R.; Tharnish, P.M.; Clark, J.; Hollecker, L.; Lostia, S.; Nachman, T.; Grier, J.; Bennett, M.A.; Xie, M.Y.; et al. Inhibition of hepatitis C replicon RNA synthesis by $\beta$-D-2'- deoxy-2'-fluoro-2'-C-methylcytidine: A specific inhibitor of hepatitis $C$ virus replication. Antivir. Chem. Chemother. 2006, 17, 79-87. [CrossRef] [PubMed]

57. Sofia, M.J.; Furman, P.A. The Discovery of Sofosbuvir: A Liver-Targeted Nucleotide Prodrug for the Treatment and Cure of HCV. In HCV Journey from Discovery to a Cure; Springer Nature Switzerland AG: Basel, Switzerland, 2019; pp. 223-247.

58. Reiss, S.; Rebhan, I.; Backes, P.; Romero-Brey, I.; Erfle, H.; Matula, P.; Kaderali, L.; Poenisch, M.; Blankenburg, H.; Hiet, M.-S.; et al. Recruitment and Activation of a Lipid Kinase by Hepatitis C Virus NS5A Is Essential for Integrity of the Membranous Replication Compartment. Cell Host Microbe 2011, 9, 32-45. [CrossRef]

59. Appel, N.; Zayas, M.; Miller, S.; Krijnse-Locker, J.; Schaller, T.; Friebe, P.; Kallis, S.; Engel, U.; Bartenschlager, R. Essential role of domain III of nonstructural protein 5A for hepatitis $C$ virus infectious particle assembly. PLoS Pathog. 2008, 4. [CrossRef]

60. Romero-Brey, I.; Berger, C.; Kallis, S.; Kolovou, A.; Paul, D.; Lohmann, V.; Bartenschlager, R. NS5A domain 1 and polyprotein cleavage kinetics are critical for induction of double-membrane vesicles associated with hepatitis c virus replication. MBio 2015, 6, 1-12. [CrossRef]

61. Lemm, J.A.; O’Boyle, D.; Liu, M.; Nower, P.T.; Colonno, R.; Deshpande, M.S.; Snyder, L.B.; Martin, S.W.; St. Laurent, D.R.; Serrano-Wu, M.H.; et al. Identification of Hepatitis C Virus NS5A Inhibitors. J. Virol. 2010, 84, 482-491. [CrossRef]

62. Lohmann, V.; Korner, F.; Dobierzewska, A.; Bartenschlager, R. Mutations in Hepatitis C Virus RNAs Conferring Cell Culture Adaptation. J. Virol. 2001, 75, 1437-1449. [CrossRef] [PubMed]

63. Gao, M.; Nettles, R.E.; Belema, M.; Snyder, L.B.; Nguyen, V.N.; Fridell, R.A.; Serrano-Wu, M.H.; Langley, D.R.; Sun, J.H.; O'Boyle, D.R.; et al. Chemical genetics strategy identifies an HCV NS5A inhibitor with a potent clinical effect. Nature 2010, 465, 96-100. [CrossRef] [PubMed]

64. Pietilä, M.K.; Hellström, K.; Ahola, T. Alphavirus polymerase and RNA replication. Virus Res. 2017, 234, 44-57. [CrossRef]

65. Varghese, F.S.; Kaukinen, P.; Gläsker, S.; Bespalov, M.; Hanski, L.; Wennerberg, K.; Kümmerer, B.M.; Ahola, T. Discovery of berberine, abamectin and ivermectin as antivirals against chikungunya and other alphaviruses. Antivir. Res. 2016, 126, 117-124. [CrossRef]

66. Lani, R.; Hassandarvish, P.; Chiam, C.W.; Moghaddam, E.; Chu, J.J.H.; Rausalu, K.; Merits, A.; Higgs, S.; Vanlandingham, D.; Abu Bakar, S.; et al. Antiviral activity of silymarin against chikungunya virus. Sci. Rep. 2015, 5, 11421. [CrossRef] 
67. Lani, R.; Hassandarvish, P.; Shu, M.-H.; Phoon, W.H.; Chu, J.J.H.; Higgs, S.; Vanlandingham, D.; Abu Bakar, S.; Zandi, K. Antiviral activity of selected flavonoids against Chikungunya virus. Antivir. Res. 2016, 133, 50-61. [CrossRef] [PubMed]

68. Wichit, S.; Hamel, R.; Bernard, E.; Talignani, L.; Diop, F.; Ferraris, P.; Liegeois, F.; Ekchariyawat, P.; Luplertlop, N.; Surasombatpattana, P.; et al. Imipramine Inhibits Chikungunya Virus Replication in Human Skin Fibroblasts through Interference with Intracellular Cholesterol Trafficking. Sci. Rep. 2017, 7, 3145. [CrossRef] [PubMed]

69. Fros, J.J.; Liu, W.J.; Prow, N.A.; Geertsema, C.; Ligtenberg, M.; Vanlandingham, D.L.; Schnettler, E.; Vlak, J.M.; Suhrbier, A.; Khromykh, A.A.; et al. Chikungunya virus nonstructural protein 2 inhibits type I/II interferon-stimulated JAK-STAT signaling. J. Virol. 2010, 84, 10877-10887. [CrossRef] [PubMed]

70. Albulescu, I.C.; van Hoolwerff, M.; Wolters, L.A.; Bottaro, E.; Nastruzzi, C.; Yang, S.C.; Tsay, S.-C.; Hwu, J.R.; Snijder, E.J.; van Hemert, M.J. Suramin inhibits chikungunya virus replication through multiple mechanisms. Antivir. Res. 2015, 121, 39-46. [CrossRef] [PubMed]

71. Wada, Y.; Orba, Y.; Sasaki, M.; Kobayashi, S.; Carr, M.J.; Nobori, H.; Sato, A.; Hall, W.W.; Sawa, H. Discovery of a novel antiviral agent targeting the nonstructural protein 4 (nsP4) of chikungunya virus. Virology 2017, 505, 102-112. [CrossRef] [PubMed]

72. Nelemans, T.; Kikkert, M. Viral innate immune evasion and the pathogenesis of emerging RNA virus infections. Viruses 2019, 11, 961. [CrossRef]

73. Wang, J.-M.; Wang, L.-F.; Shi, Z.-L. Construction of a non-infectious SARS coronavirus replicon for application in drug screening and analysis of viral protein function. Biochem. Biophys. Res. Commun. 2008, 374, 138-142. [CrossRef]

74. Payne, S. Family Coronaviridae. In Viruses; MDPI: Basel, Switzerland, 2017; pp. 149-158.

75. Malik, Y.S.; Sircar, S.; Bhat, S.; Sharun, K.; Dhama, K.; Dadar, M.; Tiwari, R.; Chaicumpa, W. Emerging novel Coronavirus (2019-nCoV)—Current scenario, evolutionary perspective based on genome analysis and recent developments. Vet. Q. 2020, 1-12. [CrossRef]

76. Cucinotta, D.; Vanelli, M. WHO Declares COVID-19 a Pandemic. Acta Biomed. 2020, 91, 157-160. [CrossRef]

77. Adedeji, A.O.; Singh, K.; Calcaterra, N.E.; DeDiego, M.L.; Enjuanes, L.; Weiss, S.; Sarafianos, S.G. Severe acute respiratory syndrome coronavirus replication inhibitor that interferes with the nucleic acid unwinding of the viral helicase. Antimicrob. Agents Chemother. 2012, 56, 4718-4728. [CrossRef]

78. Adedeji, A.O.; Singh, K.; Kassim, A.; Coleman, C.M.; Elliott, R.; Weiss, S.R.; Frieman, M.B.; Sarafianos, S.G. Evaluation of SSYA10-001 as a Replication Inhibitor of Severe Acute Respiratory Syndrome, Mouse Hepatitis, and Middle East Respiratory Syndrome Coronaviruses. Antimicrob. Agents Chemother. 2014, 58, 4894-4898. [CrossRef]

79. Ge, F.; Xiong, S.; Lin, F.-S.; Zhang, Z.-P.; Zhang, X.-E. High-throughput assay using a GFP-expressing replicon for SARS-CoV drug discovery. Antivir. Res. 2008, 80, 107-113. [CrossRef] [PubMed]

80. Norder, H.; De Palma, A.M.; Selisko, B.; Costenaro, L.; Papageorgiou, N.; Arnan, C.; Coutard, B.; Lantez, V.; De Lamballerie, X.; Baronti, C.; et al. Picornavirus non-structural proteins as targets for new anti-virals with broad activity. Antiviral Res. 2011, 89, 204-218. [CrossRef] [PubMed]

81. Xiong, Q.; Wang, Y.; Xie, B.; Pei, X.; Peng, Y. Single-step construction of a picornavirus replicon RNA with precise ends. J. Virol. Methods 2017, 248, 87-91. [CrossRef] [PubMed]

82. Tulloch, F.; Pathania, U.; Luke, G.A.; Nicholson, J.; Stonehouse, N.J.; Rowlands, D.J.; Jackson, T.; Tuthill, T.; Haas, J.; Lamond, A.I.; et al. FMDV replicons encoding green fluorescent protein are replication competent. J. Virol. Methods 2014, 209, 35-40. [CrossRef] [PubMed]

83. Belov, G.A.; Altan-Bonnet, N.; Kovtunovych, G.; Jackson, C.L.; Lippincott-Schwartz, J.; Ehrenfeld, E. Hijacking Components of the Cellular Secretory Pathway for Replication of Poliovirus RNA. J. Virol. 2007, 81, 558-567. [CrossRef] [PubMed]

84. Netzler, N.E.; Tuipulotu, D.E.; Vasudevan, S.G.; Mackenzie, J.M.; White, P.A. Antiviral candidates for treating hepatitis E virus infection. Antimicrob. Agents Chemother. 2019, 63. [CrossRef]

85. Chang, K.O.; Sosnovtsev, S.V.; Belliot, G.; King, A.D.; Green, K.Y. Stable expression of a Norwalk virus RNA replicon in a human hepatoma cell line. Virology 2006, 353, 463-473. [CrossRef]

86. Ford Siltz, L.A.; Viktorova, E.G.; Zhang, B.; Kouiavskaia, D.; Dragunsky, E.; Chumakov, K.; Isaacs, L.; Belov, G.A. New Small-Molecule Inhibitors Effectively Blocking Picornavirus Replication. J. Virol. 2014, 88, 11091-11107. [CrossRef] 
87. Gao, Q.; Yuan, S.; Zhang, C.; Wang, Y.; Wang, Y.; He, G.; Zhang, S.; Altmeyer, R.; Zou, G. Discovery of itraconazole with broad-spectrum in vitro antienterovirus activity that targets nonstructural protein $3 \mathrm{~A}$. Antimicrob. Agents Chemother. 2015, 59, 2654-2665. [CrossRef]

88. Shimizu, H.; Nakashima, K. Surveillance of hand, foot, and mouth disease for a vaccine. Lancet Infect. Dis. 2014, 14, 262. [CrossRef]

89. Wu, K.X.; Chu, J.J.H. Antiviral screen identifies EV71 inhibitors and reveals camptothecin-target, DNA topoisomerase 1 as a novel EV71 host factor. Antivir. Res. 2017, 143, 122-133. [CrossRef] [PubMed]

90. Huber, S.A.; Gauntt, C.J.; Sakkinen, P. Enteroviruses and myocarditis: Viral pathogenesis through replication, cytokine induction, and immunopathogenicity. Adv. Virus Res. 1998, 51, 35-80. [PubMed]

91. Wehbe, M.; Huguenin, A.; Leveque, N.; Semler, B.L.; Hamze, M.; Andreoletti, L.; Bouin, A. Construction of a subgenomic CV-B3 replicon expressing emerald green fluorescent protein to assess viral replication of a cardiotropic enterovirus strain in cultured human cells. J. Virol. Methods 2016, 230, 1-8. [CrossRef]

92. De Palma, A.M.; Vliegen, I.; De Clercq, E.; Neyts, J. Selective inhibitors of picornavirus replication. Med. Res. Rev. 2008, 28, 823-884. [CrossRef]

93. De Palma, A.M.; Heggermont, W.; Lanke, K.; Coutard, B.; Bergmann, M.; Monforte, A.-M.; Canard, B.; De Clercq, E.; Chimirri, A.; Pürstinger, G.; et al. The Thiazolobenzimidazole TBZE-029 Inhibits Enterovirus Replication by Targeting a Short Region Immediately Downstream from Motif $C$ in the Nonstructural Protein 2C. J. Virol. 2008, 82, 4720-4730. [CrossRef]

94. Van Der Linden, L.; Van Der Schaar, H.M.; Lanke, K.H.W.; Neyts, J.; Van Kuppeveld, F.J.M. Differential Effects of the Putative GBF1 Inhibitors Golgicide A and AG1478 on Enterovirus Replication. J. Virol. 2010, 84, 7535-7542. [CrossRef]

95. Xu, L.; Su, W.; Jin, J.; Chen, J.; Li, X.; Zhang, X.; Sun, M.; Sun, S.; Fan, P.; An, D.; et al. Identification of Luteolin as Enterovirus 71 and Coxsackievirus A16 Inhibitors through Reporter Viruses and Cell Viability-Based Screening. Viruses 2014, 6, 2778-2795. [CrossRef]

96. Kim, C.; Kang, H.; Kim, D.-E.; Song, J.-H.; Choi, M.; Kang, M.; Lee, K.; Kim, H.S.; Shin, J.S.; Jeong, H.; et al. Antiviral activity of micafungin against enterovirus 71. Virol. J. 2016, 13, 99. [CrossRef]

97. McErlean, P.; Shackelton, L.A.; Andrews, E.; Webster, D.R.; Lambert, S.B.; Nissen, M.D.; Sloots, T.P.; Mackay, I.M. Distinguishing Molecular Features and Clinical Characteristics of a Putative New Rhinovirus Species, Human Rhinovirus C (HRV C). PLoS ONE 2008, 3, e1847. [CrossRef]

98. Palmenberg, A.C.; Spiro, D.; Kuzmickas, R.; Wang, S.; Djikeng, A.; Rathe, J.A.; Fraser-Liggett, C.M.; Liggett, S.B. Sequencing and analyses of all known human rhinovirus genomes reveal structure and evolution. Science 2009, 324, 55-59. [CrossRef]

99. Mello, C.; Aguayo, E.; Rodriguez, M.; Lee, G.; Jordan, R.; Cihlar, T.; Birkus, G. Multiple classes of antiviral agents exhibit in vitro activity against human rhinovirus type C. Antimicrob. Agents Chemother. 2014, 58, 1546-1555. [CrossRef]

100. Bochkov, Y.A.; Palmenberg, A.C.; Lee, W.M.; Rathe, J.A.; Amineva, S.P.; Sun, X.; Pasic, T.R.; Jarjour, N.N.; Liggett, S.B.; Gern, J.E. Molecular modeling, organ culture and reverse genetics for a newly identified human rhinovirus C. Nat. Med. 2011, 17, 627-632. [CrossRef]

101. Yang, L.; Kiyohara, T.; Kanda, T.; Imazeki, F.; Fujiwara, K.; Gauss-Müller, V.; Ishii, K.; Wakita, T.; Yokosuka, O. Inhibitory Effects on HAV IRES-Mediated Translation and Replication by a Combination of Amantadine and Interferon-Alpha. Virol. J. 2010, 7. [CrossRef]

102. Kanda, T.; Yokosuka, O.; Imazeki, F.; Fujiwara, K.; Nagao, K.; Saisho, H. Amantadine inhibits hepatitis A virus internal ribosomal entry site-mediated translation in human hepatoma cells. Biochem. Biophys. Res. Commun. 2005, 331, 621-629. [CrossRef] [PubMed]

103. Payne, S. Family Hepeviridae. In Viruses; MDPI: Basel, Switzerland, 2017; pp. 121-124.

104. Johne, R.; Dremsek, P.; Reetz, J.; Heckel, G.; Hess, M.; Ulrich, R.G. Hepeviridae: An expanding family of vertebrate viruses. Infect. Genet. Evol. 2014, 27, 212-229. [CrossRef] [PubMed]

105. Teshale, E.H.; Howard, C.M.; Grytdal, S.P.; Handzel, T.R.; Barry, V.; Kamili, S.; Drobeniuc, J.; Okware, S.; Downing, R.; Tappero, J.W.; et al. Hepatitis E epidemic, Uganda. Emerg. Infect. Dis. 2010, 16, 126-129. [CrossRef] [PubMed]

106. Nimgaonkar, I.; Ding, Q.; Schwartz, R.E.; Ploss, A. Hepatitis e virus: Advances and challenges. Nat. Rev. Gastroenterol. Hepatol. 2018, 15, 96-110. [CrossRef] 
107. Nishiyama, T.; Kobayashi, T.; Jirintai, S.; Kii, I.; Nagashima, S.; Prathiwi Primadharsini, P.; Nishizawa, T.; Okamoto, H. Screening of novel drugs for inhibiting hepatitis E virus replication. J. Virol. Methods 2019, 270, 1-11. [CrossRef]

108. Payne, S. Family Caliciviridae. In Viruses; MDPI: Basel, Switzerland, 2017; pp. 115-119.

109. Lucero, Y.; Vidal, R.; O’Ryan, G.M. Norovirus vaccines under development. Vaccine 2018, 36, 5435-5441. [CrossRef]

110. Rocha-Pereira, J.; Neyts, J.; Jochmans, D. Norovirus: Targets and tools in antiviral drug discovery. Biochem. Pharmacol. 2014, 91, 1-11. [CrossRef] [PubMed]

111. Chang, K.-O.; George, D.W. Interferons and Ribavirin Effectively Inhibit Norwalk Virus Replication in Replicon-Bearing Cells. J. Virol. 2007, 81, 12111-12118. [CrossRef] [PubMed]

112. Bok, K.; Cavanaugh, V.J.; Matson, D.O.; González-Molleda, L.; Chang, K.O.; Zintz, C.; Smith, A.W.; Iversen, P.; Green, K.Y.; Campbell, A.E. Inhibition of norovirus replication by morpholino oligomers targeting the $5^{\prime}$-end of the genome. Virology 2008, 380, 328-337. [CrossRef]

113. Dou, D.; Tiew, K.C.; Mandadapu, S.R.; Gunnam, M.R.; Alliston, K.R.; Kim, Y.; Chang, K.O.; Groutas, W.C. Potent norovirus inhibitors based on the acyclic sulfamide scaffold. Bioorganic Med. Chem. 2012, 20, 2111-2118. [CrossRef] [PubMed]

114. Mandadapu, S.R.; Gunnam, M.R.; Galasiti Kankanamalage, A.C.; Uy, R.A.Z.; Alliston, K.R.; Lushington, G.H.; Kim, Y.; Chang, K.O.; Groutas, W.C. Potent inhibition of norovirus by dipeptidyl $\alpha$-hydroxyphosphonate transition state mimics. Bioorganic Med. Chem. Lett. 2013, 23, 5941-5944. [CrossRef] [PubMed]

115. Amblard, F.; Zhou, S.; Liu, P.; Yoon, J.; Cox, B.; Muzzarelli, K.; Kuiper, B.D.; Kovari, L.C.; Schinazi, R.F. Synthesis and antiviral evaluation of novel peptidomimetics as norovirus protease inhibitors. Bioorganic Med. Chem. Lett. 2018, 28, 2165-2170. [CrossRef]

116. Harmalkar, D.S.; Lee, S.J.; Lu, Q.; Il Kim, M.; Park, J.; Lee, H.; Park, M.; Lee, A.; Lee, C.; Lee, K. Identification of novel non-nucleoside vinyl-stilbene analogs as potent norovirus replication inhibitors with a potential host-targeting mechanism. Eur. J. Med. Chem. 2019, 184. [CrossRef]

(C) 2020 by the authors. Licensee MDPI, Basel, Switzerland. This article is an open access article distributed under the terms and conditions of the Creative Commons Attribution (CC BY) license (http://creativecommons.org/licenses/by/4.0/). 